\title{
生体膜輸送の分子機構に関する生物薬剤学的研究
}

过彰

\section{Biopharmaceutical Studies on Molecular Mechanisms of Membrane Transport}

\author{
Akira TsuJI \\ Faculty of Pharmaceutical Sciences, Kanazawa University \\ 13-1 Takara-machi, Kanazawa 920-0934, Japan
}

(Received August 27, 2002)

\begin{abstract}
By incorporating the transporter-mediated or receptor-mediated transport process in physiologically based pharmacokinetic models, we succeeded in the quantitative prediction of plasma and tissue concentrations of $\beta$-lactam antibiotics, insulin, pentazocine, quinolone antibacterial agents, and inaperizone and digoxin. The author's research on transporter-mediated pharmacokinetics focuses on the molecular and functional characteristics of drug transporters such as oligopeptide transporter, monocarboxylic acid transporter, anion antiporter, organic anion transporters, organic cation/carnitine transporters (OCTNs), and the ATP-binding cassette transporters P-glycoprotein and MRP2. We have successfully demonstrated that these transporters play important roles in the influxes and/or effluxes of drugs in intestinal and renal epithelial cells, hepatocytes, and brain capillary endothelial cells that form the blood-brain barrier. In the systemic carnitine deficiency ( $\mathrm{SCD}$ ) phenotype mouse model, juvenile visceral steatosis (jvs) mouse, a mutation in the OCTN2 gene was found. Furthermore, several types of mutation in human SCD patients were found, demonstrating that OCTN2 is a physiologically important carnitine transporter. Interestingly, OCTNs transport carnitine in a sodiumdependent manner and various cationic drugs transport it in a sodium-independent manner. OCTNs are thought to be multifunctional transporters for the uptake of carnitine into tissue cells and for the elimination of intracellular organic cationic drugs.
\end{abstract}

Key words — - transporters; P-glycoprotein; intestinal absorption; blood-brain barrier; $\beta$-lactam antibiotics; carnitine

\section{1. はじめに}

医薬品の適正使用並びに医薬品開発における薬物 の体内動態特性の重要性が広く認識され, 科学的実 証に基づいた薬物動態影響因子を解明する研究に多 大の関心が寄せられるようになった。多くの生体側 因子の中で，薬物の組織細胞膜透過性は薬物動態影 響因子として極めて重要である。

生体は細胞内外の栄養素や内因性物質の選択的物 質交換によって必要物質の摂取と, 生体異物や老廃 物の排除を行っているが，その選択性は細胞膜に備 わるトランスポーター群の輸送機能に依存してい る. 最近になって，栄養物や内因性物質のトランス ポーター群に関する分子生物学的研究成果が報告さ れるに伴い, 体内の各組織細胞膜に備わるトランス

金沢大学薬学部（广920-0934 金沢市宝町 13-1）

e-mail: tsuji@kenroku.kanazawa-u.ac.jp

*本総説は, 平成 14 年度日本薬学会学会賞の受賞を記 念して記述したものである.
ポーター群の薬物構造認識・輸送機能は, それら遺 伝子発現細胞や遺伝子欠損マウスなどの利用によっ て実証されつつある. 生体にとって「必要なもの」 を積極的に取り込み, 「不要なもの」を細胞外へ排 出する機能を担うトランスポーターの分子機構の解 明に多大の関心が寄せられている。

1975 年から生物薬剂学的研究に従事して今日に 至るまで著者は, 小腸, 肝臓, 腎臓及び血液脳関門 (blood-brain barrier，以下 BBB と略す）の機能を 備える脳毛細血管内皮細胞など生体各組織細胞膜に おいて薬物輸送に関与するトランスポーター群の存 在と薬物動態決定因子としてのその重要性を明らか にするとともに, トランスポーター遺伝子の単離・ 組織分布・局在性解析とその構造認識・輸送特性を 利用した医薬品の適正使用並びに創薬への戦略を確 立するために, 分子生物学的手法を取り入れた生物 薬剂学的研究を進めてきた。 トランスポーターは, 生体機能の維持に重要であると同時に, 生体内に投 


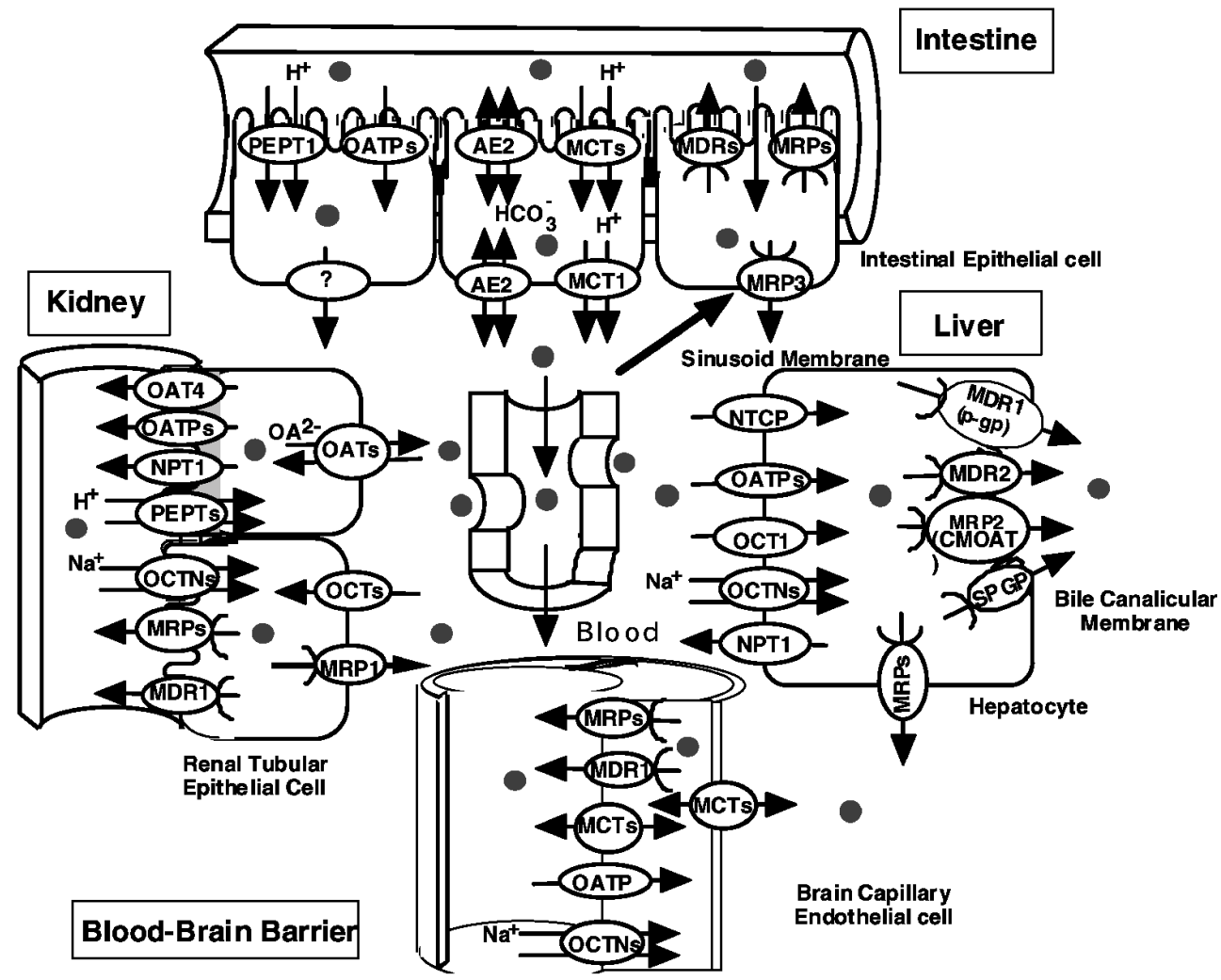

Fig. 1. Human Membrane Transporters Expressed in Intestine, Kidney, Liver, Blood-Brain Barrier and Tumor

与された薬物の(1)投与部位から循環血中への吸収過 程，(2)組織への分布・移行過程，(3)薬効又は毒性発 現部位との相互作用，(4)肝代謝・胆汁排泄及び腎尿 細管分泌など薬物の吸収・分布・排泄の諸過程に関 与している. 現在までに分子レベルで構造が明らか にされたトランスポーターの中で, 薬物又はその代 謝物の輸送に関わる薬物トランスポーターは, 一次 性能動輸送系, 二次性能動輸送系を含め, Fig. 1 に 示すように極めて多様である.これら取り込みと排 出に関わるトランスポーター群に対する親和性とこ れらによる輸送の大小を調節することによって, 体 内動態上の特性を目的に適合させて制御できること になり, 臓器特異的なトランスポーターの性質を考 慮した創薬分子デザインも可能になると考えられる.

以下に著者が歩んできた道を概説し, 薬物体内動 態研究の将来について展望したい.

\section{2. $\boldsymbol{\beta}$-ラクタム抗生物質の体内動態支配因子の解} 明

薬物間の体内動態の違いを決定付ける主たる要因 は, 毛細血管透過性, 組織細胞内外への輸送・排出 動態, 特定組織での代謝, 血漿タンパク質及び組織
細胞内夕ンパク質との結合性, 血流速度, 細胞間液 量などである.

ペニシリンやセファロスポリンなどの $\beta$-ラクタ 厶抗生物質の水溶液中における安定性に関する速度 論的研究で学位を 1976 年に取得した著者は, これ らの抗生物質を生体内に投与した後の体内動態支配 因子の解明に取りかかった，その研究の方向は，(1) 静脈内投与後の分布容積が細胞間隙容量に近似して いるのはなぜか, (2)多くの誘導体の中で経口吸収さ れるものの化学構造が $\alpha$ 位にアミノ基を有するも のに限定されているのはなぜか, (3)体内からの排泄 を尿中排泄と胆汁排泄に振り分ける分子機構はどの ようなものか，(4)脳内に直接投与すると重篤な痤攣 を誘発するにもかかわらず，全身投与ではそのよう な中枢性の副作用が誘起されないのはなぜか, とい う疑問点を生物薬剤学的に解明することに向けた。 これらの問題解決の鍵は $\beta$-ラク夕ム抗生物質の組 織細胞膜透過性にあるとの考えに至り, 以下に述べ る研究を着手した。

$\beta$-ラクタム抗生物質の分布容積が例外なく細胞 間隙容量に近似していることに着目し, その組織分 
布性は「各組織の細胞間液量と細胞間液中のアルブ ミン量とアルブミンに対する薬物の結合性により決 まる」という仮説を立て「細胞外液モデル」を提案 した. ${ }^{1)} こ の$ 組織分布の機構に加えて, 肝蔵及び腎 臓ではそれぞれの固有クリアランスに従って胆汁中 及び尿中に排泄されるという機構を生理学的モデル に組み込み, 各組織每に立てられた連立微分方程式 をコンピュータを用いて数值積分することにより， $\beta$-ラクタム抗生物質をラット, ウサギ及びヒトに 静注後の組織濃度一時間推移を予測することに成功 した. ${ }^{2,3)}$ さらに同モデルを用い，加齢に伴う $\beta$-ラ クタム抗生物質の組織分布性の変動は組織細胞間液 量の変化に依存していることを明らかにした. ${ }^{4-7)}$ 後にはこれらの成果を基礎に, 高分子量ペプチド性 薬物の体内動態解析に適用した。特に, インスリン が腎臓で受容体介在型エンドサイトーシスされるこ とを灌流法を用いて実証した. ${ }^{8)}$ さらに, 肝臓にお けるインスリンの分布と消失を「受容体再循環モデ ル」により解析し, 糖尿病時には肝細胞膜表面上の インスリン受容体が増加するために, インスリンの 体内動態が変動することを明らかにした. ${ }^{9)}$

生理学的モデル解析法は, 生理・解剖学的実体に 即しているので, 個々のパラメータを対象とする動 物ごとにあらかじめ設定することが容易であり，し たがって「動物からヒト」, 「正常から病態」, 「試験 管内（in vitro）から個体（in vivo）」における薬物 動態の予測を可能とする方法としての評価が定着し つつある。その特徵から, 医薬品の有用性と安全性 を考慮した医薬品開発のツールとして, 合理的な投 与設計の確立に, 妊娠時における薬物の胎児への移 行動態の予測, さらに副作用発現の予測とその回避 など高い利用価值を有している. ${ }^{9-16)}$

一方, 薬物の組織細胞間液中濃度は薬効を支配す る要因であるが，これを組織微小透析法により実測 する方法論の確立に成功した. ${ }^{17,18)}$ 本手法の確立に よって, 細胞内酵素により代謝されやすい不安定薬 物の組織細胞間液中濃度を実測する道が開かれ

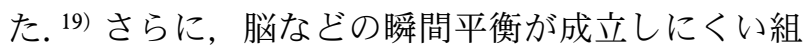
織中の細胞間液中非結合形薬物濃度の測定が可能と なった. ${ }^{20)}$

これらの一連の研究で, 当時助教授として研究室 の研究を指揮していた寺崎哲也博士（現東北大大学 院・教授）が本学会 1992 年度奨励賞を受賞した.
詳細は，寺崎博士の総説21)に記載されている.

3. 消化管吸収に関与する薬物トランスポーター 群の分子認識・輸送特性

薬物の消化管吸収に関する研究は, 1960 年代の 生物薬剂学 (biopharmaceutics) が誕生した初期の ころから我が国を中心に行われ，生体外異物として の薬物は $\mathrm{pH}$-分配仮説に従って小腸上皮細胞を単 純拡散で透過するという薬物吸収機構が広く受け入 れられてきた。したがって薬物の小腸吸収機構に関 しては研究の余地がないと思われていた。しかし， 生理的物質のトランスポーター介在輸送に関する細 胞生理学的研究が活発になるにつれ, 薬物の消化管 上皮細胞における輸送機構は, 従来考えられていた ほど単純ではなく, トランスポーター群が薬物の吸 収・分泌に関与するなど, 極めて複雑であることが 次第に明らかにされつつある.

3-1. オリゴペプチドトランスポーターを介する 薬物吸収 $\beta$-ラクタム抗生物質の小腸からの吸 収と消化管腔における分解を分離して評価する研 究22)を行っていた過程で, これらの $\beta$-ラクタム抗 生物質の一部が小腸オリゴペプチドトランスポー ターを介して吸収されることを発見し, その輸送系 の実体解明に向けて今日まで研究を続けてき た. ${ }^{23-40)}$ 著者らを含め世界の多くの研究機関か ら，このオリゴペプチドトランスポーターがペプチ ド性薬物（構造式を Fig. 2 に示す）の吸収に関与 していることが, 刷子縁膜小胞や培養上皮細胞 Caco-2 を用いた実験系によって提唱されてき た. ${ }^{41-43)}$ 一方, 薬物との相互作用による小腸上皮 細胞膜表面の荷電状態変化が見かけ上担体介在輸送 様吸収現象を示すとの観点から $\beta$-ラク夕ム抗生物 質の吸収におけるトランスポーターの関与に否定的 な考え方が報告された. ${ }^{41-43)}$

これらの議論の過程で著者は, 薬物輸送の膜生理 学的研究結果からのみでは, 薬物動態を決定してい る因子が薬物と生体との物理的相互作用によるもの であるのか, 機能タンパク質との相互作用にあるの かを明らかにすることは困難であり, 新しい研究手 法を生物薬剤学の領域に取り込む必要性を痛感し た. 薬物投与後の血中濃度や組織内濃度の時間推移 を薬物速度論的に捉える研究手法を用いて, 異なる 条件下で得られた実測值を定量的に予測し得たとし ても, その事象を決定している真の要因を実証した 


\section{$\beta$-lactam antibiotics}
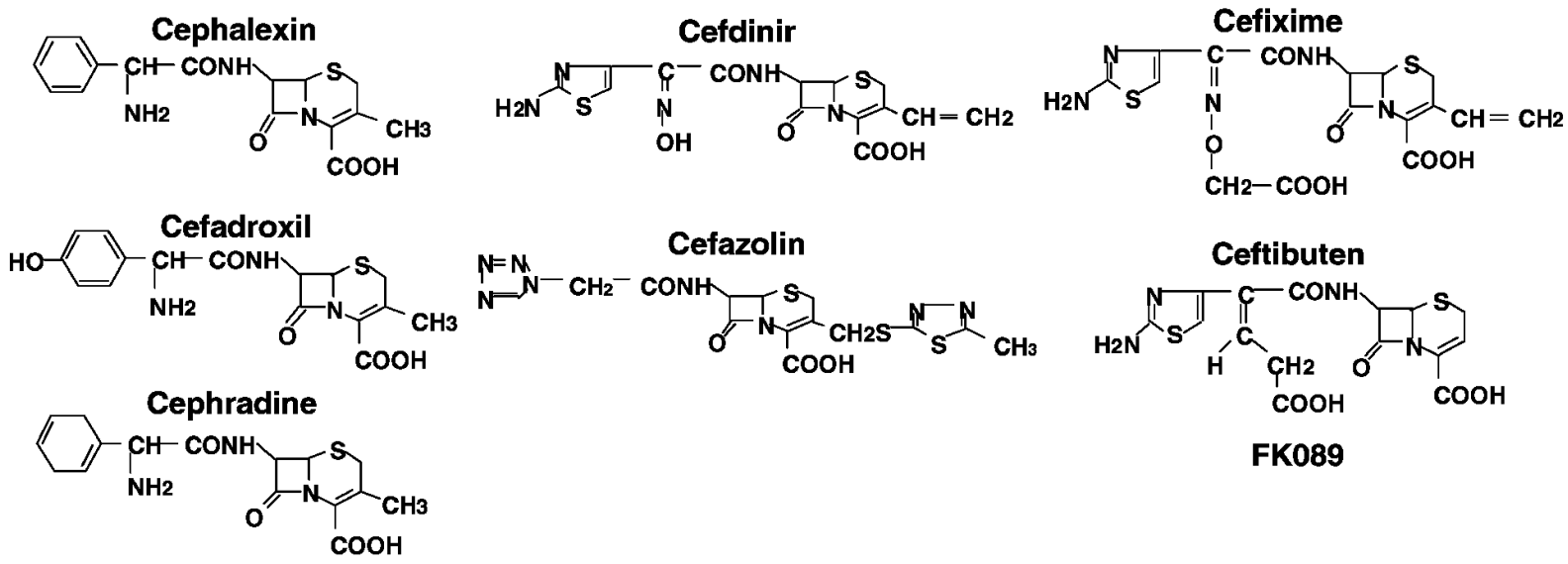

$\alpha$-Methyldopa-L-Phenylalanine

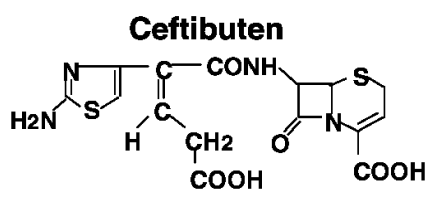

FK089

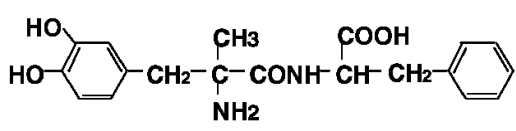

L-dopa-L-Phenylalanine

Val-acyclovir<smiles>CC(C)C(N)C(=O)OCCOCn1cnc2c(=O)[nH]c(N)nc21</smiles>

Fig. 2. Chemical Structures of $\beta$-Lactam Antibiotics and Drugs Transported by PEPT1

ことにはならない．分子生物学的手法を薬物動態研 究の領域に取り入れることが今後の動態研究の発展 に必須と判断し, 分子生物薬剂学 (molecular biopharmaceutics）の誕生に向けて第一歩に踏み込 んだ。 P-450に代表される代謝研究の領域において は既に導入されていた分子生物学的手法ではあった が，著者らがトランスポーター遺伝子発現系細胞系 を導入した研究成果を本学会年会や雑誌で発表した 1992 年前後では世界のどの研究機関においても動 態研究には採用されていなかった。 その後, トラン スポーター研究がその輸送系の実体を遺伝子など分 子レベルで解明する方向に向けて急速な発展を遂げ ることとなった。

著者らはまず，ウサギ小腸上皮細胞に存在するヌ クレオシドトランスポーターをアフリカツメガエル 卵母細胞に発現させ，そのヌクレオシド誘導体に対 する輸送能を測定するという, 本番に向けた遺伝子
導入実験を行った. ${ }^{44)} こ の$ 経験を生かして, ラッ 卜，ウサギ，ヒト小腸上皮細胞由来の mRNA を注 入した卵母細胞に， $\beta$-ラクタム抗生物質を選択的 に取り込むオリゴペプチド $/ \mathrm{H}^{+}$共輸送系の発現を 確認し, $\beta$-ラクタム抗生物質の小腸細胞膜輸送に おいて動物種に関わらずトランスポータータンパク 質が関与していることを明らかにした。 ${ }^{35,36)} し か$ し，残念ながらこのオリゴペプチドトランスポー ター遺伝子をクローニングするには至らなかった。

1994 年 Fei らは，ウサギ小腸 mRNA の $2.9 \mathrm{~kb}$ 分 画から 12 回膜貫通領域を有し，707 個のアミノ酸 で構成されるオリゴペプチド $/ \mathrm{H}^{+}$トランスポー ターPEPT1 遺伝子クローニングに成功した. ${ }^{45)}$ $P E P T 1$ 遺伝子の単離は分子生物薬剂学の世界的発 展に大きく貢献した業績といって過言ではない。こ の成果を受けて，著者ら及び Saito らはラット小腸 より, Liang らはヒト小腸より PEPTI 遺伝子を単 


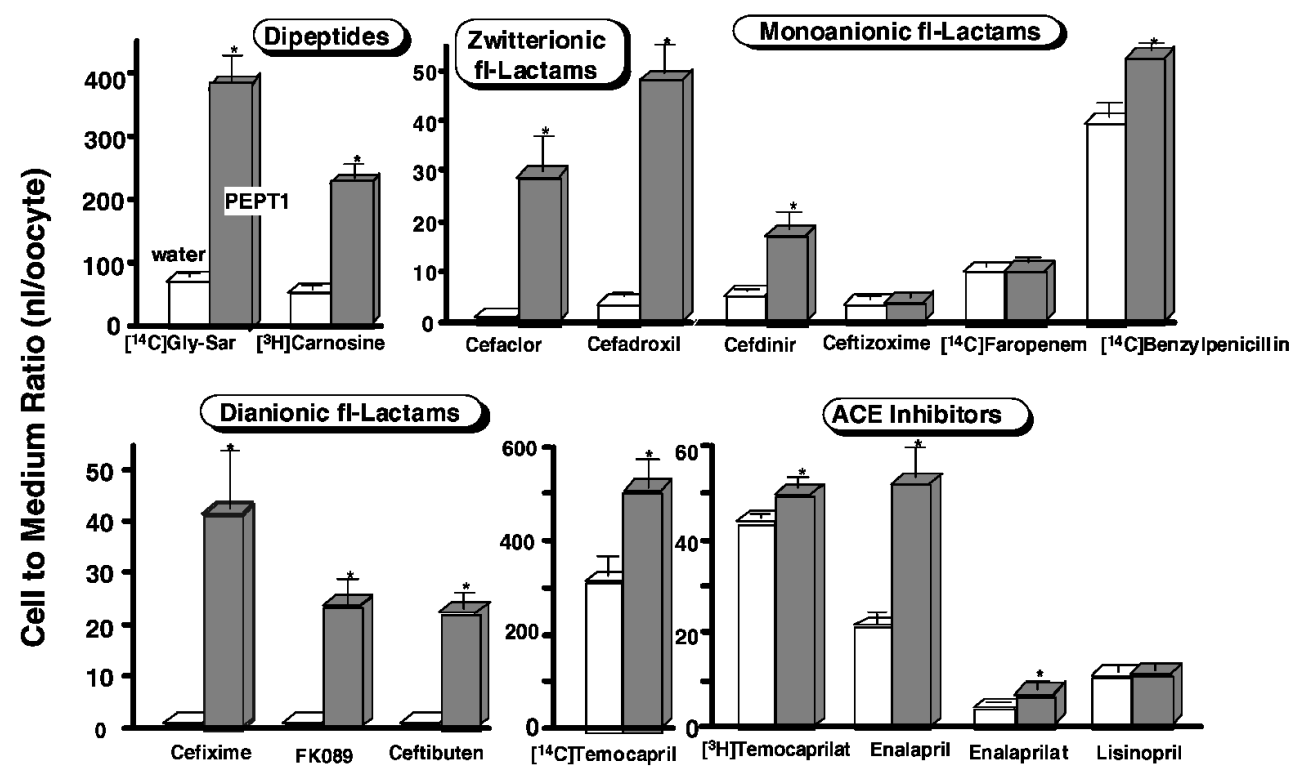

Fig. 3. Uptake of Dipeptides, $\beta$-Lactam Antibiotics and ACE Inhibitors by Xenopus Laevis Oocytes Injected with Human PEPT1 cRNA

Uptake of $\beta$-lactam antibiotics was measured at $25^{\circ} \mathrm{C}$ and $\mathrm{pH} 6.0$ for $1 \mathrm{hr}$ or $2 \mathrm{hr}$ by Xenopus laevis oocytes injected with human PEPT1 cRNA (closed) or water alone (open). Substrate concentrations were: $\left[{ }^{3} \mathrm{H}\right]$ carnosine, $0.6 \mu \mathrm{M} ;\left[{ }^{14} \mathrm{C}\right] \mathrm{Gly}-\mathrm{Sar}, 50 \mu \mathrm{M} ;\left[{ }^{14} \mathrm{C}\right]$ faropenem, $20 \mu \mathrm{M} ;\left[{ }^{14} \mathrm{C}\right]$ benzylpenicillin, $55 \mu \mathrm{M} ;\left[{ }^{14} \mathrm{C}\right]$ temocapril, $\left.10 \mu \mathrm{M} ;{ }^{3} \mathrm{H}\right]$ temocaprilat: $0.1 \mu \mathrm{M}$; ther others, $2 \mathrm{mM}$. Each column represents the mean + S.E. of three to fifteen experiments. *Significantly different compared with uptake by water-injected oocytes $(p<0.05)$.

離した. ${ }^{37,46,47)}$ 著者らはラットPEPT1cRNA をアフ リカツメガエル卵母細胞に発現させその輸送機能を 測定した。経口用 $\beta$-ラクタム抗生物質のセファド ロキシル, セファレキシン, セフラジン, セフィキ シムにおいて, セフチブテンにおいてはそのシス幾 何異性体に輸送活性が検出された。一方, セフチブ テンのトランス異性体と注射剤として臨床適用され ているセファゾリンにはそのような活性は観測され ず，PEPT1 の輸送活性と $\beta$-ラク夕ム抗生物質のラ ット小腸吸収性との間に良好な関連性が見られた。

Figure 3 に示すように，ヒトPEPT1 が $\beta$-ラクタム 抗生物質に対してはラットPEPT1 と同様の輸送活 性を示すばかりでなく，エナラプリル，テモカプリ ルなどの ACE 阻害薬をも輸送することを実証し た.さらに, PEPT1 の部分塩基配列に対するアン チセンスオリゴヌクレオチドにより mRNA 中に含 まれるPEPT1 遺伝子の発現を特異的に抑制する hybrid depletion 実験を行つた. その結果, mRNA を注入しない場合と同程度まで活性が低下した. ${ }^{38)}$

以上の結果は, 小腸上皮細胞オリゴペプチド輸送 系を介する $\beta$-ラクタム抗生物質輸送をほぼすべて PEPT1 が担っていることを意味している.さらに 著者らはPEPT1 に対するペプチド抗体を作製し,
本トランスポーターが刷子縁膜にのみ局在している ことを明らかにした。 ${ }^{39)}$ ラット小腸においても同様 の局在性が確認されている. PEPT1は, 動物種に よっても多少変わるが, 小腸のほか, 肝臓, 腎蔵に 発現がある。PEPT1の転写開始点より $1.5 \mathrm{~kb} の$ $5^{\prime}$ 上流域を組み込んだ発現ベクターを細胞に発現さ せたところ, 小腸及び腎由来の $\mathrm{Caco}-2$ 及び OK 細 胞にのみプロモーター活性が確認された。したがつ て, この領域内に PEPT1 の転写開始点より $350 \mathrm{bp}$ 以内に臓器特異的発現に必須の領域が存在すること が示唆された。 また, 転写開始点より $295 / 277$ bp 領域にはアミノ酸による PEPT1 発現促進に関する 領域が確認できた. ${ }^{40)}$

$\beta$-ラクタム抗生物質以外のペプチド様化合物と して, 抗がん剤のベスタチン, 一部のレニン阻害薬 においてもオリゴペプチドトランスポーターの関与 が示されている. ${ }^{41-43)}$ 最近, ペプチド結合を有し ない 4-アミノーフェニル酢酸も PEPT1 によって認 識・輸送されることが報告された。 著者らも, 抗ウ イルス薬シクロビルの吸収向上を意図して開発され たバリンとのエステル誘導体, バルアシクロビル （Fig. 2）が PEPT1によって輸送されることを遺伝 子発現細胞を用いて実証した. ${ }^{48)}$ 
他の輸送系に比べ，オリゴペプチドトランスポー ターの幅広い基質認識性を利用すれば，低吸収性の 親化合物のペプチド化修飾によって薬物吸収促進が 期待できる。この戦略を実証するため，アミノ酸卜 ランスポーターによる輸送効率が劣るために経口後 のバイオアベイラビリティーに問題のある高血圧治 療薬 $\alpha$-メチルドーパ及びパーキンソン病治療薬 $\mathrm{L}-$ ドーパと L-フェニルアラニンとのジペプチドプロ ドラッグをデザインし (Fig. 2 参照)，それぞれ親 化合物の消化管吸収性の向上に成功した. ${ }^{49,50)}$

3-2. モノカルボン酸トランスポーターを介する 薬物吸収弱酸性化合物の消化管吸収には酸性 $\mathrm{pH}$ で増大する $\mathrm{pH}$ 依存性が観測される。この $\mathrm{pH}$ 依存性は従来より $\mathrm{pH}$-分配仮説によって説明され てきたが，酢酸のような短鎖乳酸に限らず，乳酸， ニコチン酸，安息香酸，サリチル酸，プラバスタチ ンなどのモノカルボン酸系化合物の小腸上皮細胞輸 送に $\mathrm{H}^{+}$共輸送系が関与する吸収機構を刷子縁膜小 胞又は Caco-2 細胞を用いた研究成果 ${ }^{52-61)}$ に基づい て提唱した。

1994 年, チャイニーズハムスター卵巣（CHO） 細胞から, 乳酸及びピルビン酸のプロトン共輸送体 として $M C T 1$ 遺伝子がクローニングされた. ${ }^{62)}$ そ こで CHO-MCTI 遺伝子によるノーザン解析によ って，ラット及びウサギ小腸，及び $\mathrm{Caco}-2$ 細胞膜 画分に MCT1 に対応するシグナルを確認し, 小腸 上皮細胞における MCT1 の存在を示すことができ
た. ${ }^{63)}$ そこで，ラット小腸遺伝子ライブラリーから の $M C T 1$ 遺伝子のクローニングを行い, ラット MCT1cDNA を得ることができた. ${ }^{64)}$ ラット MCT1 は494 個のアミノ酸からなり，アミノ酸配列で八ム スター及びヒト MCT1 と $93.1 \%$ 及び $84.6 \%$ の相同 性を有するものと推測された。また， hydropathy plot 解析の結果, 12 回膜貫通ドメインを有する典 型的なトランスポーターとしての構造を有してい た。ラット MCT1 を発現させた細胞を用いて，そ の機能解析を行った結果, $\mathrm{L}$-乳酸, ピルビン酸に 加え, 酷酸, プロピオン酸, 酪酸などの短鎖脂肪 酸, 二コチン酸のほか, アニオン性 $\beta$-ラクタム抗 生物質の 1 つベンジルペニシリン, 安息香酸やバル プロ酸も本トランスポーターによって運ばれ, 薬物 吸収にも働いていることが示された. ${ }^{64,65)}\left[{ }^{14} \mathrm{C}\right]$ 安息 香酸の MCT1 による時間依存的（A）及び $\mathrm{pH}$ 依 存的（B）取り込みを Fig. 4 に示す. ${ }^{66}$

$\beta$-ラクタム抗生物質には前述したオリゴペプチ ドトランスポーターを介して吸収される誘導体があ るが，一部モノカルボン酸トランスポーターを介す る場合も考えられる。セフジニルはモノカルボン酸 構造を有するセファロスポリン系抗生物質である が，著者らはオリゴペプチドトランスポーター以外 にアニオンとしての認識を受けることを示唆する結 果を得ており, ${ }^{34)}$ 本輸送系の関与が示唆される。 た，ラットMCT1による取り込みは，乳酸やキラ ル構造を有する各種モノカルボン酸化合物に対する

A

B
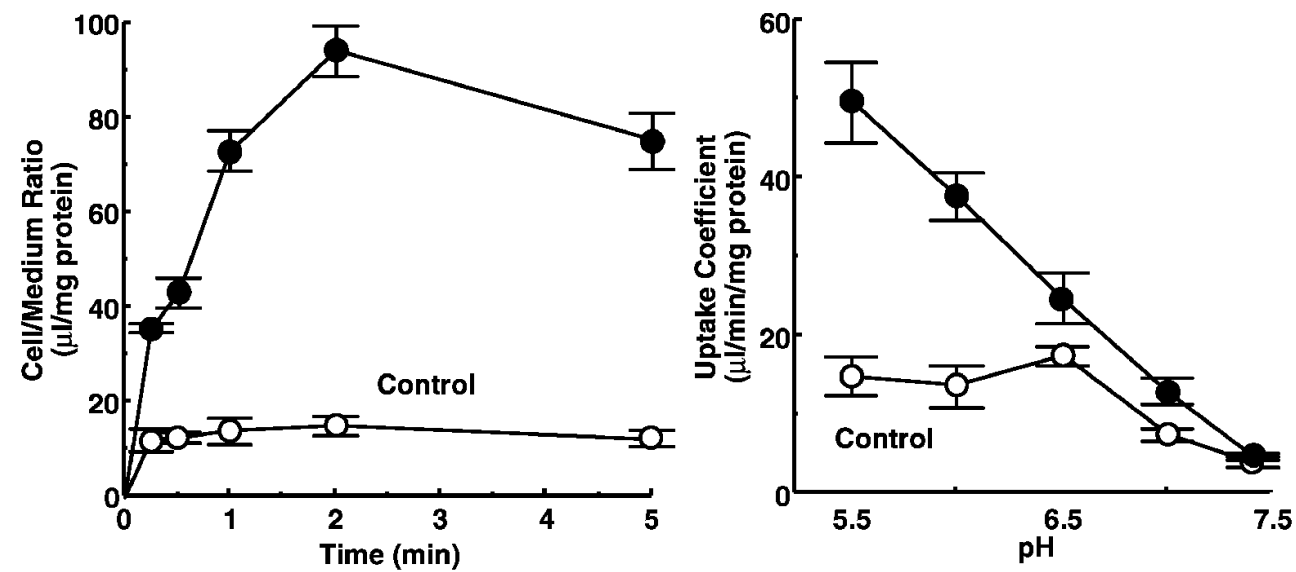

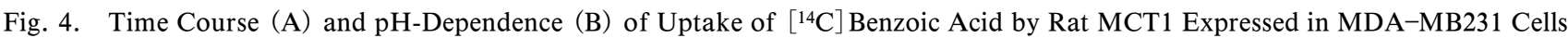
Uptake of $\left.{ }^{[14} \mathrm{C}\right]$ benzoic acid was measured for MDA-17B231 cells transfected with rat MCT1 $(\mathbf{O})$ or with pRc-CMV vector alone $(\mathrm{O})$. Each point represents the means + S.E. of four experiments. 


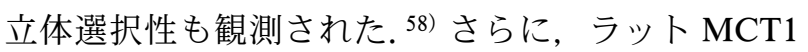
に対する抗ペプチド抗体を作製しウェスタン解析を 行った結果, ラット小腸刷子縁膜及び側基底膜に MCT1 が検出された. ${ }^{65)}$ MCT1 のモノカルボン酸輸 送の駆動力は内側に向けられたプロトン勾配である ので，ラット小腸上皮細胞において MCT1 は，刷 子縁膜近傍の microclimate 酸性 $\mathrm{pH}$ 環境 $(5.8-6.2)$ を利用してモノカルボン酸を消化管管腔から細胞内 (pH 約 7.2) に, 細胞内から門脈系への吸収方向の 輸送に関与していると推察される.

また, ノーザンブロット解析から, 脳, 心臓, 腎 臓, 肝臓, 肺, 筋肉など多くの臓器に存在し, 特に 心臓に多く存在した。したがって, MCT1 は多く の臓器で生理的役割を有しており, ${ }^{64)}$ 特に高い乳酸 代謝活性が要求される心臓においてはその発現量が 多くなっているものと考えられる．脳にも分布が見 られたことから，物質の脳移行性にとって重要な BBBにおける存在を検討した。 ラット脳毛細血管 内皮の初代培養細胞を調製し, 得られた遺伝子及び 膜画分を用いた RT-PCR 法, 及びウェスタン解析 を行った。その結果， BBBにも MCT1 が存在する ことが確認され，モノカルボン酸の血液-脳間物質
交換に MCT1 が一部機能していることを示すこと ができた. ${ }^{66)}$

一方，著者らはモノカルボン酸化合物の小腸吸収 においてアニオン交換輸送系が関与することを主張 してきた. Figure 5 には種々モノカルボン酸系化合 物のプロトンあるいは重炭酸イオン勾配存在下にお ける, ウサギ小腸刷子縁膜小胞への初期取り込みを 示す．点線で示してあるのはいずれのイオン勾配も 与えない場合の取り込みであるが，プロトン勾配あ るいは重炭酸イオン勾配それぞれの存在下で初期取 り込みに促進が見られた。一方，興味深いことにモ ノカルボン酸構造を有する高脂血漿治療薬のプラバ スタチンや，その部分構造を形成するメバロン酸に はプロトンとの共輸送系を介した輸送が起こるが, アニオン逆輸送系に対してはほとんど親和性を持た

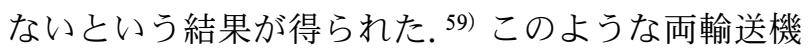
構の基質認識性の違いは，アニオン交換輸送系がプ ロトン共輸送系とは独立した機構として存在するこ とを示唆している.

アニオンとの逆輸送系としては, 赤血球の塩素イ オン/重炭酸イオン交換体であるアニオン交換輸送 系ファミリーの 1 つである AE2 が小腸刷子縁膜に

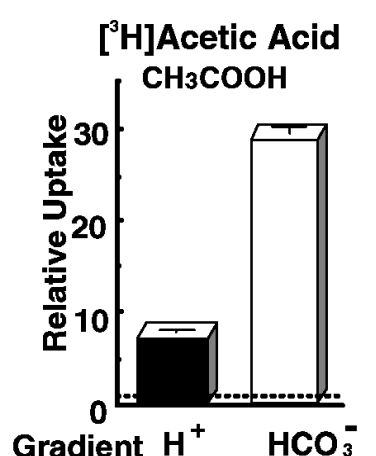

$\left[{ }^{14} \mathrm{C}\right]$ Valproic Acid

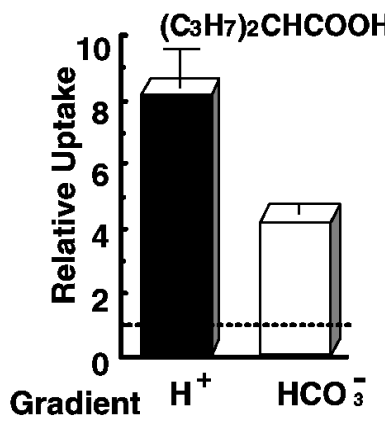

$\left[{ }^{14} \mathrm{C}\right]$ Benzoic Acid

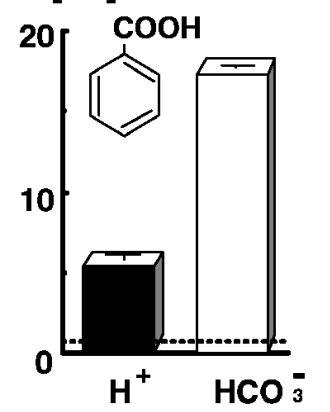

L-[ $\left[{ }^{14} \mathrm{C}\right]$ Lactic Acid

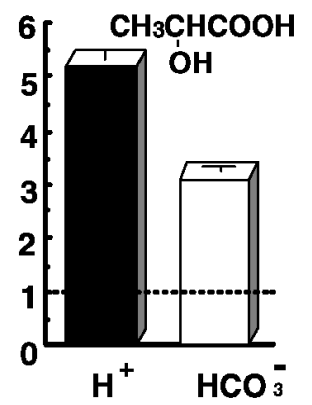

$\left[{ }^{14} \mathrm{C}\right]$ Nicotinic Acid

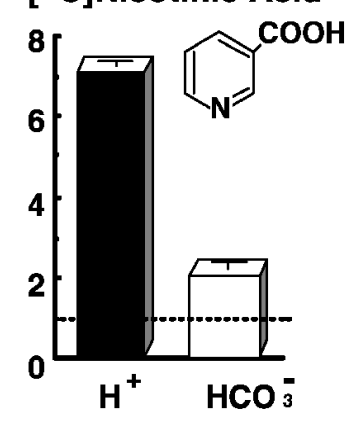

(R)-[ $\left.{ }^{3} \mathrm{H}\right]$ Mevalonic Acid $\quad\left[{ }^{14} \mathrm{C}\right]$ Pravastatin
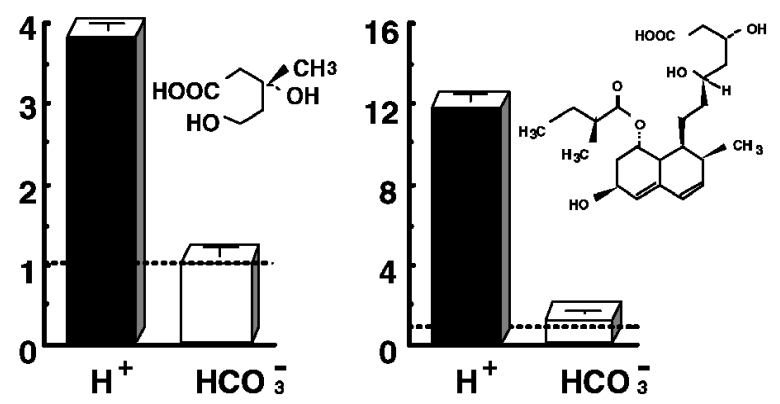

Fig. 5. Proton and Bicarbonate Dependencies for Transports of Various Monocarboxylic Acids

Initial uptake of various monocarboxylic acids was determined in the presence of proton (closed) or bicarbonate ion (open) gradient and shown by relative value to the uptake in the absence of any ion gradient. 
発現しているので，著者らはその一部を担うものと 考えている。本研究を開始した当時では，AE2 は バンド 3 タンパクと同様に塩素イオンや硫酸イオン トランスポーターであると考えられている程度であ つた。著者らはマウス $A E 2$ 遺伝子を米国スタンフ オード大学 Kopito 教授から譲り受け, 有機アニオ ン輸送活性について検討した。マウス AE2 をヒト 腎由来 HEK293 細胞に発現させ機能解析を行った 結果, 安息香酸, ニコチン酸などのモノカルボン酸 系化合物に対し顕著な輸送活性を示した. ${ }^{76)} \mathrm{RT}-$ PCR 法を用いた解析により小腸には AE ファミ リーのうち AE2 が最も多く発現しているので，し たがってアニオン逆輸送系の 1 つとして AE2 がモ ノカルボン酸系化合物の吸収に働くことが示唆され る.

モノカルボン酸系化合物の消化管吸収に寄与する と推測されるトランスポーターの同定は，今後の吸 収一基質構造相関研究に有用な情報を与えるものと 期待される。しかし，MCT1 あるいは AE2 に認識 されないが，小腸刷子縁膜小胞や Caco-2 において 内向きのプロトン勾配を駆動力とするトランスポー ターによって輸送されるメバロン酸やプラバスタチ ンのようなモノカルボン酸系化合物もある. 恐らく モノカルボン酸トランスポーターには多様性があ り，プロトン共輸送系としての MCT1，アニオン 逆輸送系としての AE2 以外のさらなる有機アニオ ン輸送系が存在し, 化合物により役割分担して生理 機能を維持していると同時に, 弱酸性薬物の $\mathrm{pH}$ 依 存的消化管吸収に関与することを強く示すものであ る。なお，現在では MCT ファミリーとして MCT1 一MCT8 までが報告されており, ${ }^{144)}$ それらの組織 分布とモノカルボン酸薬物輸送能との関係に関心が 寄せられている.

3-3. リン酸トランスポーターを介する薬物吸収 抗ウィルス薬フォスカルネットは, ウサギで $95 \%$ と薬物の水溶性から推測されるよりも高い吸収性 と, ヒトやラット，マウスにおいては 20-30\%前 後で, 動物種差が大きい吸収特性を有している. ${ }^{68)}$ 著者らは, ラット小腸刷子縁膜小胞へのフォスカル ネットの取り込みを測定したところ，ナトリウムイ オン勾配存在下で典型的なオーバーシュートを示 し, またその初期取り込みには飽和性, リン酸輸送

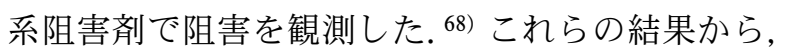

フォスカルネットがリン酸輸送系を介して吸収され ることが分かる．また著者らは，同様に分子内にリ ン酸基を有する抗生物質ホスホマイシンにおいても 一部リン酸トランスポーターが関与する吸収機構を 報告した. ${ }^{69,70)}$

\section{ABC トランスポーターを介する薬物排出}

$\mathrm{P}$-糖タンパク質は ATP の加水分解により得られ るエネルギーを駆動力とする薬剤排出ポンプとして 機能する ABC（ATP-binding cassette）スーパーフ アミリーに属するトランスポーターである。この糖 タンパク質は, 腫瘍細胞の多剂耐性化因子として見 出され, ビンカアルカロイド, アントラサイクリン 系抗がん剂など種々薬物を腫瘍細胞内から汲み出す ことにより，耐性化を引き起こす，P-糖タンパク 質は抗腫瘍薬のみならず，ステロイドホルモン，免 疫抑制薬のシクロスポリンやタクロリムス, さらに ベラパミルなどのカルシウム拮抗薬, 抗不整脈薬シ ゴキシンも輸送するなど，極めて幅広い基質認識性 を有し，細胞外に輸送する. ${ }^{71)}$

著者は, 1988 年頃より腫瘍細胞が上記のように 薬剂排出ポンプを細胞膜上に備えることによって細 胞内の薬剤濃度を低下させ細胞を守る巧妙な機能に 関心を持っていた，著者が薬物など生体異物に対す る生体防御機構を解明したいとの思いを温めていた 背景には，(1)大腸菌が $\beta$-ラクタム抗生物質に接触 した数時間の内に細胞膜透過性を低下させることに よって耐性を獲得したと思われる現象を発見してい たこと, ${ }^{72,73)}$ (2)数種の二ューキロン系抗菌剤は, 消 化管上皮細胞, 血球や筋肉, 肺などの組織細胞膜を 容易に透過するにも関わらず，BBB の透過性が極 めて低く, 脳脊髄液関門より排出輸送されるという 現象を発見したこと, ${ }^{74,75)}$ があった。折しも 1989 年, $\beta$-ラク夕ム抗生物質の消化管 - 肝臓 - 腎臓に おけるトランスポーター介在輸送の臟器間相関研究 で薬学博士（東京大）の学位が授与された玉井郁巳 助手は, $\mathrm{P}-$ 糖タンパク質の基質認識に関する研究 のためシカゴ大学医学部 Safa 博士の元に留学し, 1990 年シクロスポリンが P-糖タンパク質の基質と なることを初めて明らかにした. ${ }^{76)}$ はからずも, 本 トランスポーターは腫瘍細胞のみならず，腎蔵，肝 臓, 腸管, 副腎, 一部の毛細血管内皮細胞など正常 な組織にも発現していることが発見され, ${ }^{71,77-79)}$ そ の発現組織における $\mathrm{P}-$ 糖タンパク質の生理的役割 
と薬物輸送における役割の解明に関心が寄せられた が不明のままであった。

4-1. P-糖タンパク質のBBB 機能薬物の脳 移行は，BBB を形成して多岐にわたる物質輸送機 能を有する脳毛細血管内皮細胞によって厳密に制御 されている. 脳血液間の物質交換のメカニズムを理 解した上での適切な薬物デザインが理想的である.

薬物などの非生理的物質においては, 透過する分 子の脂溶性と分子サイズによって決まる単純拡散が 薬物の脳移行性の重要な決定因子であると考えられ ている. 事実, Fig. 6 に示されるように多くの化合 物の見かけの脳移行性は, $\mathrm{n}$ 一オクタノール/水間分 配係数や拡散係数などの物理化学的特性と良い相関

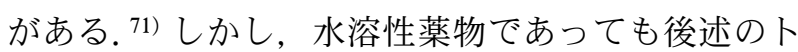
ランスポーターを介して BBB を効率的に透過する ことが明らかにされている。一方，シクロスポリ ン, ビンクリスチン, エピポドフィロトキシン, ド キソルビシンはいずれもそれらの脂溶性から予測さ れるよりはるかに低い透過性を示している. 1980 年以来この現象は, 分子量 500 以上の物質の BBB 透過が制限されるためと考えられてきた. ${ }^{71,77-79)}$

上述のように玉井郁巳博士によってシクロスポリ ンが P-糖タンパク質の基質であることが発見され たことを契機に, 1992 年に著者らは同じく同年に 鶴尾らは，これらの物質が脳毛細血管内皮細胞管腔 側膜に存在する $\mathrm{P}-$ 糖タンパク質によって能動的に 内皮細胞から血液側に排出されるためであることを 脳毛細血管内皮細胞培養系を用いて世界で初めて実 証した。 ${ }^{80)}$ また, 著者らはラット脳虚血再灌流系を
用い, シクロスポリンとドキソルビシンの脳移行が ATP 依存的な P-糖タンパク質の機能によって制御 されていることを実証することに成功した ${ }^{81-83)}$ が，残念ながら P-糖タンパク質が in vivoにおいて 実際に排出ポンプとして機能していることを分子レ ベルで証明するに至らなかったため, 1992 年以来 2 年間は空白の時代を迎えた. しかし 1994 年に至 り, オランダ癌研究所のグループによって, 脳にお ける $\mathrm{P}-$ 糖タンパク質をコードする遺伝子 mdrla を ノックアウトしたマウスにおいてビンブラスチン及 びイベルネクチンの脳移行が正常マウスのそれぞれ 20 倍及び 80 倍以上に増大することが発見された ${ }^{84)}$ ので，上記に示す著者ら及び鶴尾らの「P-糖タン パク質の BBB 機能」仮説が正しいことが裏付けさ

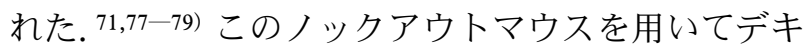
サメサゾン, ジゴキシン, シクロスポリン, オンダ ンセトロンなどの脳内移行が mdr1a 欠損マウスに おいて有意に増大することを示す Schinkel らの実 験成績が蓄積した. ${ }^{71,77-79)}$ 最近著者らは, mdrla/ $m d r 1 b$ 遺伝子欠損マウスを用いた検討により脂溶 性のニューキノロン系抗菌薬のグレパフロキサシン, HSR-903, シプロフロキサシン（Fig. 7）及び免疫 抑制薬タクロリムスの BBB 透過が $\mathrm{P}-$ 糖タンパク質 の排出によって制限されていることを確認し た. ${ }^{85,86)}$

したがって，BBB は静的な脂質膜バリヤーでは なく, 生体必須物質やその構造類似薬物を特異的輸 送機構により脳内に取り込み, 積極的な汲み出し機 構によって高脂溶性の細胞毒性物質や生体異物の脳
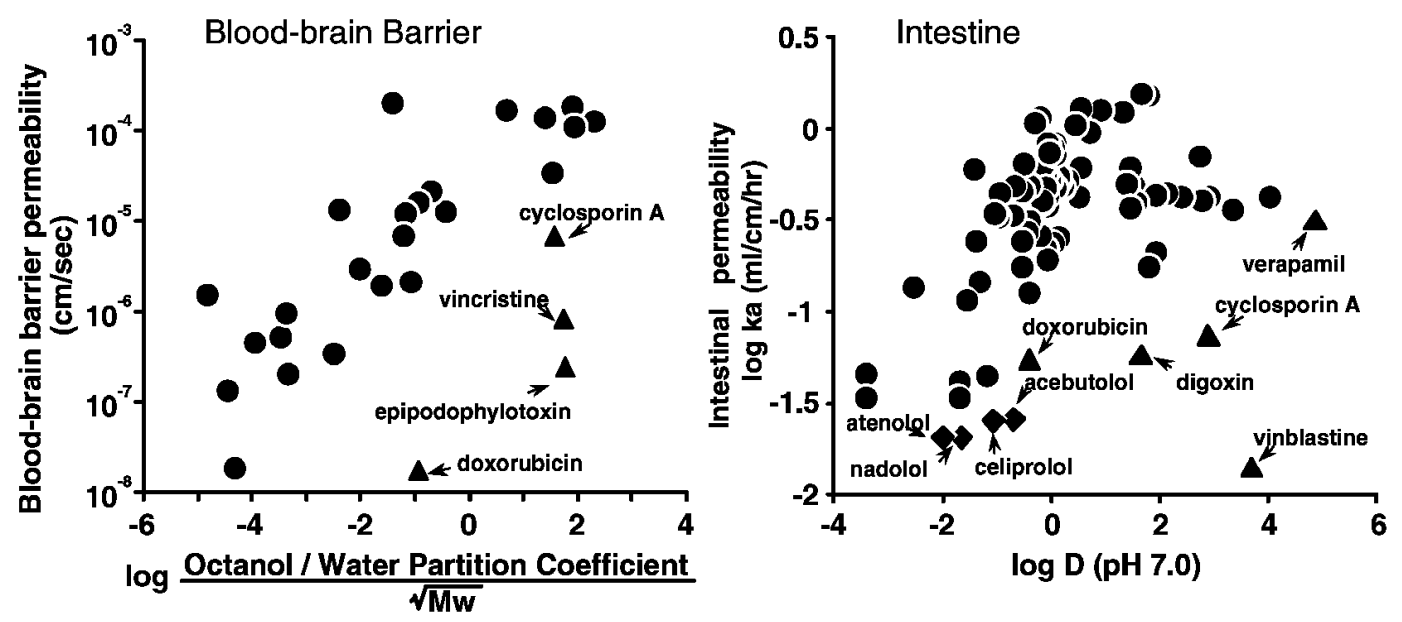

Fig. 6. Relationship between Lipophilicity and Blood-Brain Barrier or Intestinal Epithelial Permeability of Various Drugs 


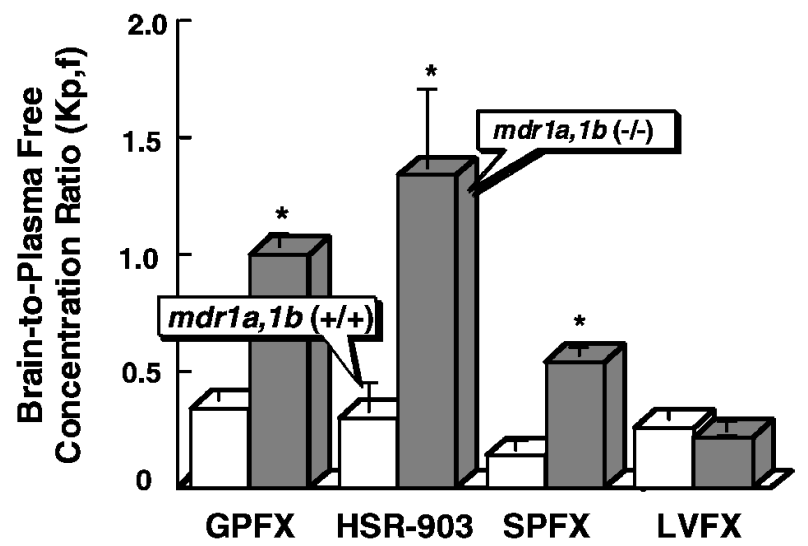

Fig. 7. Brain-to-Plasma Free Concentration Ratio $\left(\mathrm{K}_{\mathrm{p}, \mathrm{f}}\right)$ of New Quinolones, Grepafloxacin (GPFX), HSR-903, Spalfloxacin (SPFX) and Levofloxacin (LVFX), after I.V. Administration in mdrla, $1 b(+/+)$ and $m d r l a, 1 b(-/-)$ Mice

Dose: $\left.\left[{ }^{14} \mathrm{C}\right] \mathrm{GPFX}, 34 \mathrm{nmol} / \mathrm{head} ;\left[{ }^{14} \mathrm{C}\right] \mathrm{HSR}-903,0.36 \mu \mathrm{mol} / \mathrm{head}\right)$; $\left.\left[{ }^{[14} \mathrm{C}\right] \mathrm{SPFX}\right), 0.11 \mu \mathrm{mol} / \mathrm{head} ;\left[{ }^{14} \mathrm{C}\right] \mathrm{LVFX}, 19 \mathrm{nmol} / \mathrm{head}$. Each column represents the mean + S.E. of three to six experiments. *Significantly different compared with mdrla, $1 b(+/+)$ mice $(p<0.05)$.

内への侵入を防ぐなど，血液中と脳実質細胞間液中 の物質輸送を制御するダイナミックインターフェイ スとして機能しているものと考えられる.

BBB には mdr1 以外に, MRP (multidrug resistance-associated protein) のような $\mathrm{ABC}$ transporter superfamily のほか, $\beta$-ラクタム抗生物質やプロベ ネシド, PAH など多くの有機アニオンを排出する トランスポーター群が存在する。 $\beta$-ラクタム抗生 物質は, BBB のみならず血液脳脊髄液関門（脈絡 叢上皮細胞）に存在する両有機アニオントランス ポーターによって排出されるために脳に移行し難い と考えられている. ${ }^{79)}$

脳毛細血管内皮細胞に発現するこれらの排出輸送 系は，脳における生理的恒常性を維持するための生 体異物解毒機構として機能している. したがって, 中枢作用型薬物にあっては, 排出トランスポーター に認識・輸送され難い薬物をデザインすることが有 用である。脳腫瘍に抗がん剂が効を奏しない場合に は, 薬剤排出機能を阻害する薬物との併用が考えら れる。，一方，中枢において副作用が問題となる薬物 にあっては, 上述のニューキノロン系抗菌薬のよう に排出トランスポーターに認識・輸送されやすい化 合物を選択することは 1 つの創薬戦略である.

4-2. ABCトランスポーターを介した小腸管腔 内分泌 $\mathrm{P}$-糖タンパク質は小腸上皮細胞刷子縁
膜側に発現しており，種々化合物の吸収障壁として 働いていることは容易に推測される. Figure 6 は多 くの化合物の吸収速度と各化合物の脂溶性との関係 をプロットした結果である. ${ }^{81)}$ 黒丸で示される化合 物群においては脂溶性の増大とともに吸収性も増大 し, 次第に最大吸収速度に達していると解釈でき る.これに対して三角又は菱形で示したいくつかの 化合物は, 黒丸について得られる相関曲線と比較す ると著しく吸収性が低い。その中には， $\beta$ ブロッ カー, シクロスポリン, ビンブラスチン, ジゴキシ ンなど $\mathrm{P}-$ 糖タンパク質によって輸送される化合物 が多く含まれている. ${ }^{87)}$

5- $\mathrm{HT}_{3}$ レセプターアンタゴニストであるアザセ トロンは，健常人に経口投与後のバイオアベイラビ リティは $87 \%$ 以上であり, $58 \%$ が未変化体として 尿中に排泄される，アザセトロンは極めて水溶性で ありながら，さらに脂溶性の高い同効薬オンダンセ トロンよりも吸収性が優れている。 ラットにおける 経ロバイオアベイラビリティは, $10 \mathrm{mg} / \mathrm{kg}$ の低用 量では $30 \%$ に過ぎないが, 投与量の増大と共に非 線形的に増大し， $30 \mathrm{mg} / \mathrm{kg}$ では $90 \%$ にもなる. 静 脈内投与後の体内動態は線形性を示すことから, 吸 収と分泌の過程にトランスポーターの関与が考えら れた. ${ }^{88)}$ アザセトロンの in situ ラット消化管吸収速 度定数は，濃度の上昇とともに増大するが，一定濃 度以上になると減少するという, 極めて複雑な非線 形的消化管吸収現象が観測された。そこで，観測さ れる非線形的吸収現象は,「アザセトロン $10 \mathrm{~mm}$ 程 度までの吸収速度定数の増加はシクロスポリンと同 様な管腔内排出型輸送系の飽和によって, さらに $10 \mathrm{~mm}$ 以上の濃度で見られる速度の減少は吸収方 向に働く輸送系の飽和によって生じる」という仮説 を立て，その実証を行った。筋層を剥離したラット 小腸切片を装着した Ussing チャンバーの粘膜側, 及び漿膜側それぞれからのアザセトロンのフラック スの濃度依存性を測定した。その結果を Fig. 8 に 示すが，漿膜側から粘膜側へのフラックスは濃度の 上昇とともに低下したが, 逆方向のフラックスは 5 $\mathrm{mm}$ 前後までは増大し, それ以上の濃度では減少傾 向を示した. さらに低濃度領域では分泌方向のフラ ックスが吸収方向に比べ顕著に高い值を示した。し たがって, 分泌方向のフラックスの濃度依存的低下 は，低濃度側で高い活性を示す分泌に働くトランス 


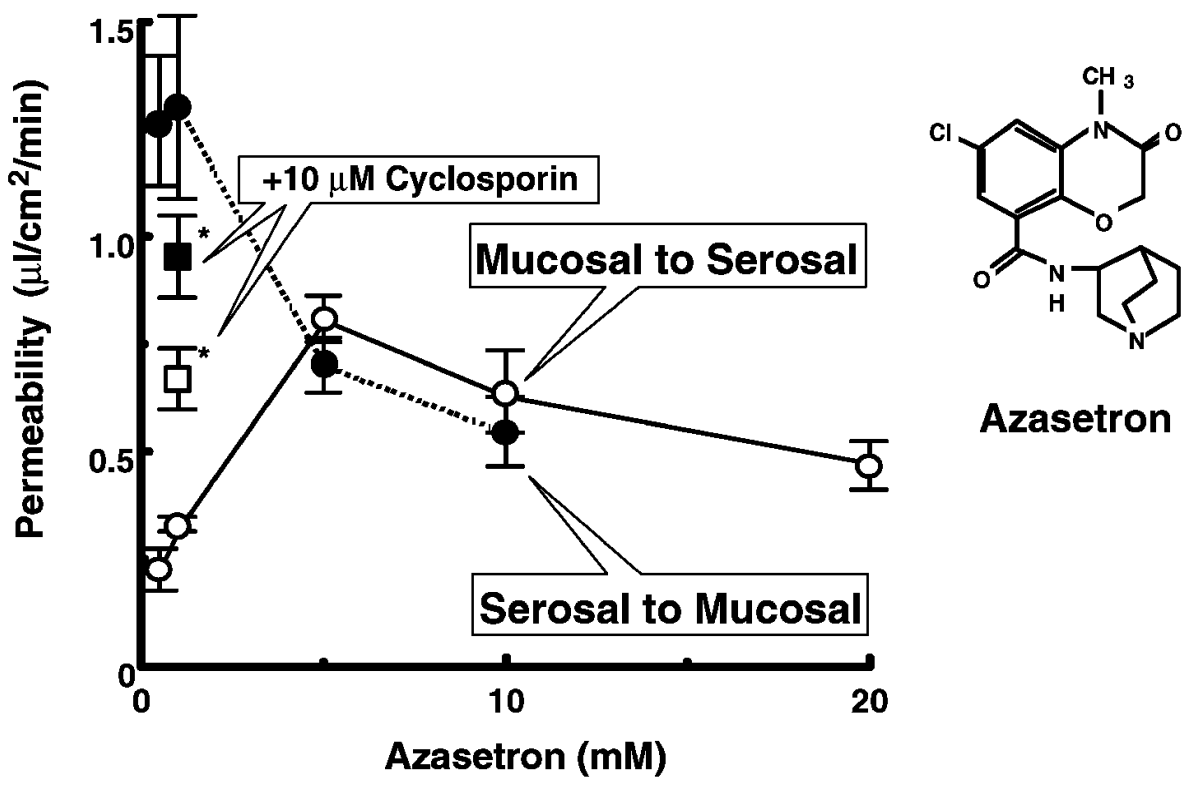

Fig. 8. Concentration Dependence of Permeability of Azasetron across Rat Ileal Tissue Mounted on Ussing Chamber

Permeability of azasetron across rat intestinal tissue from serosal-to-mucosal (closed) or mucosal-to-serosal (open) directions were measured in the presence (square) or absence (circle) of cyclosporin. Each point represents the mean \pm S.E. of three to four experiments. *Significantly different compared with the flux in the absence of cyclosporin $(p<0.05)$.

ポーターの飽和によって説明できる. 一方, 粘膜側 から漿膜側へのフラックスの低濃度側での上昇は同 じく分泌機構の飽和, 及び高濃度領域での低下は吸 収機構の飽和によって説明できる. 分泌機構として $\mathrm{P}-$ 糖タンパク質の関与の可能性について, $\mathrm{P}-$ 糖夕 ンパク質の特異的阻害剂シクロスポリンを用いた検 討を加えた。 シクロスポリン $10 \mu \mathrm{M}$ 存在下での低 濃度アザセトロンのフラックスは分泌方向は低下 し, 逆に吸収方向は増加した。Caco-2 細胞におい ても P-糖タンパク質による分泌輸送を確認すると 同時に, 取り込みに働くトランスポーターの関与が 示唆された. ${ }^{88)}$

以上の結果から, 小腸において薬物の一部は $\mathrm{P}-$ 糖タンパク質を介して分泌され，P-糖タンパク質 は管腔内排出に働くことによって吸収障壁となり種 々の生体異物に対する防御機構として機能している ものと推測される. 分泌輸送のみの場合にはバイオ アベイラビリティの低下が予想されるが, 吸収方向 にトランスポーターの関与がある場合には良好な吸 収が期待される，アザセトロンのヒトにおける良好 で個体差の少ないバイオアベイラビリティは, 吸収 方向のトランスポーターの関与があるためと思われ る.

小腸上皮細胞刷子縁膜には $\mathrm{P}-$ 糖タンパク質の他
にMRP2 が発現している.Caco-2 細胞を用いた実 験から，MRP2 がパラアミノ馬尿酸 (PAH) など の有機アニオンの小腸管腔への排出に関与している と推測される結果を得ている. ${ }^{89)}$ グレパフロキサシ ンや HSR-903 などのニューキノロン系抗菌薬は P 一糖タンパク質と MRP2 の基質であるが, 両排出ポ ンプによって消化管管腔に分泌されるにもかかわら ず，経口バイオアベイラビリティが良好である。こ れは，小腸上皮細胞にはニューキノロン系抗菌薬の 吸収に働くトランスポーターが備わっているためで ある. ${ }^{90,91)}$

なお，最近著者はこのような吸収方向に機能する トランスポーターをパスポートタンパク質 passport protein, 生体異物の解毒に関わる排出トランス ポーターや代謝酵素をゲートウエイタンパク質 gateway protein と呼称している。これらのタンパ ク質が，それぞれ生体にとって「必要なもの」を細 胞内に取り込み, 「不要なもの」を細胞外に排除す る分子機構を担っているものと思われる.

\section{5. 薬物の BBB 透過制御機構}

水溶性のグルコース, アミノ酸, モノカルボン 酸, アミン, カルニチンなどの栄養物質や $\mathrm{T} 3$ など のホルモンを循環血液中から選択的に取り込むため に，BBBにはそれぞれ独立したトランスポーター 
が備わっている。これらの栄養物トランスポーター は, 親水性の基質を比較的高い透過速度で運ぶこと ができるので，基質の構造認識特性が高いという制 約はあるが脳へのドラッグデリバリーに利用でき る. ${ }^{71,77-79,92-94)}$

以下に, 薬物のトランスポーター介在 BBB 透過 が確認できた著者らの最新の研究成果を述べる.

5-1. トランスポーターが介在する酸性薬物輸送 乳酸, 短鎖脂肪酸などの弱酸性化合物は, モノカル ボン酸輸送系を介して BBB を透過する. ${ }^{95-100)}$ 著者 らがラット小腸からクローニングしたモノカルボン 酸トランスポーターMCT1 は, 脳毛細血管内皮細 胞中にも存在し, 弱酸性化合物輸送機能の一部を担 つている. ${ }^{57,97)}$ モノカルボン酸輸送系については脳 からの排出方向の活性が高いという示唆もある. 著 者らは一部の $\mathrm{HMG}-\mathrm{CoA}$ 還元酵素阻害薬, サリチ ル酸やバルプロ酸などもモノカルボン酸系化合物特 異的なトランスポーターを介して脳内に取り込まれ ることを明らかにした. ${ }^{98-100)}$

5-2. トランスポーターが介在する塩基性薬物輸 送塩基性薬物は, 細胞が有する負の膜電位ある いは細胞表面の負電荷と薬物分子の正電荷との複雑 な相互作用による単純拡散とトランスポーターが関 与する BBB 透過があるが, その区別はしばしば困 難である．高脂溶性のプロプラノロールやリドカイ ンの BBB 透過には単純拡散と塩基性薬物特異的な 促進拡散の関与が示唆されている. ${ }^{101-106)}$

第 1 世代抗ヒスタミンであるメピラミンはプロプ ラノロール，イミプラミン, リドカインと同様にア ミン輸送系を介して BBB を透過する. ${ }^{103-104)}$ セチ リジンのように分子内にアミノ基とカルボキシル基 を有する両性イオン型の抗ヒスタミン薬は第 1 世代 のカチオン型抗ヒスタミン薬（シプロヘプタジン, ケトチフェンなど）に比してメピラミンを輸送する トランスポーターに対する親和性が低く, 中枢神経 系への移行性が低下する. ${ }^{105)}$ 第 2 世代抗ヒスタミ ン薬のテルフェナジンとエバスチンは一種のプロド ラッグであり経口投与後活性体である両性型のカル ボン酸代謝物（前者はへキソフェナジン, 後者はカ レバスチン）となる，カレバスチンはメピラミント ランスポーターに対する親和性が低いばかりでなく, $\mathrm{P}$-糖タンパク質によって脳内血管内皮細胞より排 出される（すなわち BBB を透過し難い）ため, 副
作用としての鎮静作用が回避される. ${ }^{105,106)}$ このよ うに小腸と BBB に備わるトランスポーターに対す る親和性の相違を利用すれば, 経口投与後, 小腸上 皮細胞を効率よく透過させ，かつ脳移行性を制限す ることによって中枢神経系での副作用を軽減できる.

5-3. 吸着介在型エンドサイトーシスを利用した ペプチドの脳デリバリーレセプター介在型エン ドサイトーシスに比べ特異性が低いが，様々なペプ チドの脳デリバリーに応用性が高いと期待できる手 法が，ペプチドの正電荷と細胞膜表面に存在する糖 鎖等の負電荷との相互作用を利用する吸着介在型工 ンドサイトーシス (adsorptive-mediated endocytosis, AME）である. 著者らは, 生理活性薬物とし て分子量約 1,000 , 等電点 10 の $\kappa$-受容体への結合 性を保ったままで安定性を向上させたダイノルフィ ン類似ペプチド E-2078（H-MeTyr-Gly-Gly-PheLeu-Arg-MeArg-D-Leu-CONHEt）及び ACTH の 類似体でアルツハイマー型抗痴呆薬として期待され た ebiratide (H-Met $\left(\mathrm{O}_{2}\right)$-Glu-His-Phe-D-Lys-Phe $\left.-\mathrm{CONH}\left(\mathrm{CH}_{2}\right)_{8} \mathrm{NH}_{2}\right)$ の塩基性ペプチドが，初代培 養ウシ脳毛細血管内皮細胞を用いた取り込み実験に より，両ぺプチドが AME の基質となることを実証 し, さらに脳微小透析法を用いて実際に両塩基性ぺ プチドが未変化体として脳細胞間液中にまでトラン スサイトーシスされていることを確認した. ${ }^{107-110)}$ 一方, 著者らはモデルペプチドとして 001- $\mathrm{C}_{8}(\mathrm{H}-$ MeTyr-Arg-MeArg-D-Leu-CONH $\left.\left(\mathrm{CH}_{2}\right)_{8} \mathrm{NH}_{2}\right)$ と 名付けた塩基性ペプチドを基に種々誘導体を合成 し，そのエンドサイトーシス活性を測定した。その 結果, AMEには塩基性度, 脂溶性とも適度な特性 が重要であり, 過度な脂溶性, 塩基性は本機構を介 した脳デリバリーには適さないと思われた。 ${ }^{111,112)}$ AME は小腸, 腎や肝でも進行するので脳特異性を もたらすことは困難であるが，上記のモデル塩基性 ペプチドが小腸上皮細胞を AME 機構を介して輸送 されることを実証できたので, 113-115) PEPT1によ り吸収が期待できないテトラペプチド以上のペプチ ドの経口による脳デリバリー戦略として応用できる.

\section{6. 肝臓, 腎臓における薬物膜輸送の機構論的解} 析

薬物消失組織として体内動態への影響が大きい肝 臓及び腎臓においても, 組織抽出法, 遊離細胞及び 単離膜小胞の手法を用い, $\beta$-ラク夕ム抗生物質の 
膜輸送機構を検討した。その結果，肝実質細胞の側 基底膜及び胆管膜, 腎尿細管上皮細胞の側基底膜及 び刷子縁膜において機能するトランスポーターに対 する誘導体間での親和性の違いが，胆汁排泄あるい は尿中排泄に選択性を引き起こしていることを示す ことができた. ${ }^{116-122)}$

著者らはリン酸トランスポーターとしてクローニ ングしたマウス及びヒト NPT1 が $\mathrm{Na}^{+}$依存的にリ ン酸を輸送すると同時に $\mathrm{PAH}$ のみならず，ファロ ペネムなどの $\beta$-ラクタム抗生物質を $\mathrm{Na}^{+}$非依存的 に輸送する多機能性トランスポーターであることを 発見した. ${ }^{123,124)}$ 抗マウス NPT1 抗体を用いた組織 免疫染色の結果より, 肝実質細胞では側基底膜側 に，腎尿細管上皮細胞では刷子縁膜側に発現してい ることが確認されているので, NPT1 は腎尿細管刷 子縁膜上に発現して PAH を輸送することが特定で きた最初のトランスポーターとなろう。NPTI 遺伝 子発現 HEK293 細胞への $\left[{ }^{3} \mathrm{H}\right] \mathrm{PAH},\left[{ }^{14} \mathrm{C}\right]$ ベンジル ペニシリン, $\left[{ }^{3} \mathrm{H}\right]$ ファロペネムの取り込みが，細 胞外に $140 \mathrm{mM} \mathrm{Cl}^{-}$の存在により完全に阻害される ことから，NPT1 はこれらの有機アニオンの細胞か らの排出輸送に関わつていると推察される. ${ }^{123,124)}$ 一方，腎尿細管上皮細胞に発現し，PAH や $\beta$-ラク 夕ム抗生物質などの有機アニオンを輸送するトラン スポーターとして OAT1 が確認されているが，こ れは側基底膜側に発現して 2-ケトグルタル酸など ジカルボン酸との交換輸送によりこれら有機アニオ ンを細胞内に上り坂輸送することが明らかにされて いる. ${ }^{125)}$ また，有機アニオントランスポーターと してヒト OATP ファミリーをクローニングし，そ れぞれ OATP-A，OATP-B，OATP-C, OATP-D, OATP-E と命名し, それらの輸送機能を解析し た. ${ }^{126,127)}$ OATP-A と OATP-C は既にそれぞれ OATP ${ }^{128)}$ 及び LST-1 ${ }^{129)}$ として単離されていたも のと同じものであったが, OATP-B, OATP-D 及 び OATP-E は新規の有機アニオントランスポー ターであった。脳に発現する OATP-A を除く OATP ファミリーはいずれも肝蔵に発現している が, OATP-C (LST-1, OATP-2) は肝臓のみに発 現があるのに対し, 他の OATPs は肝臓以外の組織 にも発現していた. ${ }^{127-129)}$ OATP-B, -C, -D, -E は いずれも estrone-3-sulfate を基質とするが, 肝細 胞血液側膜にのみ発現する OATP-C はベンジルペ
ニシンを輸送し, 126) その estrone-3-sulfate の取り 込夕は胆汁排泄型の $\beta$-ラクタム抗生物質によって 強く阻害された。

以上の知見に基づいて， $\beta$-ラクタム抗生物質の 肝・腎排泄経路の選択性は次のように説明できる. 循環血中にある $\beta$-ラクタム抗生物質は, 肝臟にお いては側基底膜上に発現する有機アニオントランス ポーターOATP-C (LST-1) を介して肝実質細胞 内に取り込まれるが, NPT1 を介して循環血液系 に, 肝胆管膜上に発現する MRP2 を介して胆汁中 に排出されるものと推察される. 胆汁排泄型のセフ オペラゾンの胆汁排泄クリアランスが正常ラットと 比較して，MRP2 遺伝子を欠損した EHBR （Eizai Hyperbilirubinomia Rat) で著しく減少することか ら胆汁排泄における MRP2 の関与が明らかとなつ ている。一方，腎尿細管側基底膜上に発現する OAT1 は血中の $\beta$-ラクタム抗生物質やPAH など 有機アニオンを細胞内に取り込み, 刷子縁膜上に発 現する NPT1 又は MRP2 を介して，これらを尿中 に排出するものと推察される，セファゾリンに代表 される誘導体が尿中に排泄されるのに対し, セフォ ペラゾンやセフピラミドなどの一部のものが胆汁中 に排泄されるという $\beta$-ラク夕ム抗生物質の排泄経 路に関わる体内動態上の特徵は, これらトランス ポーターに対する親和性の相違によって生じている ものと思われる. ${ }^{125)}$

ニューキノロン系抗菌薬についても誘導体間で排 泄経路に選択性があることから，排泄機構について も検討した，その結果，その多くは未変化体として 尿中に排泄される75)が，グレパフロキサシンや HSR-903 などの誘導体は, 肝実質細胞の側基底膜 に備わるトランスポーターによって細胞内に取り込 まれグルクロン酸抱合され，未変化体と共に MRP2 を介して胆汁中に排泄されることを明らか にした. ${ }^{130-134)}$

このようにトランスポーターの薬物に対する親和 性が組織間で異なることの発見は, トランスポー ターを利用した薬物の組織移行性や排泄経路を合理 的に制御できる可能性を見い出したものとして，新 薬開発の新しい戦略として注目に值する.

7. カルニチントランスポーター OCTN2 の遺伝 子変異に起因する全身性カルニチン欠乏症

カルニチン $(\beta$-hydroxy- $\gamma$-trimethylaminobutyric 
acid）はあらゆる生物の各組織に存在し，極めて水 溶性の内因性物質であり, 特に脂肪酸代謝において 重要な役割を担っていることが知られている．脂肪 酸は細胞内へ移行した後，ミトコンドリア内膜へ運 搬され， $\beta$-酸化を受けることによりエネルギー生 成に重要な ATP を生成するが，脂肪酸単独ではミ トコンドリア膜を通過する事ができず，カルニチン と結合して始めてミトコンドリア膜内シャトル機構 により輸送される。ヒトでのカルニチンの供給は 肝，腎などにおける生合成（約 $25 \%$ ）と魚，肉類 などの食事からの摂取（約 75\%）により行われて おり，栄養学的にはビタミン $\mathrm{T}$ とも呼ばれてい る. ${ }^{135)}$

全身性カルニチン欠乏症 (Systemic Carnitine Deficiency； SCD）は血液, 組織中カルニチン濃度 の著しい低下を引き起こす遺伝性疾患である. それ ゆえ SCD 患者では細胞内カルニチン含量の著しい 低下を導き, 脂肪酸代謝によるエネルギ一供給が得 られず，特に心筋，骨格筋などのエネルギー産生を 脂肪酸代謝に依存している組織において，進行性の 拡張型心筋症や骨格筋症などの重篤な症状が現れ る. カルニチンは極めて水溶性の物質であることか ら, 脂質二重層で形成されている細胞膜を通過し難 いはずであるが，実際にはその透過性は良好であ る.このことはこれら細胞膜表面にカルニチンを濃 縮的に輸送する「カルニチントランスポーター」が 存在しているためと推測され，SCD 患者ではこの 推定上の「カルニチントランスポーター」の機能異 常が発症原因であると考えられていた。

糸球体濾過されたカルニチンは腎尿細管において 約 $90 \%$ が再吸収されるが，このカルニチントラン スポーターは腎臟においてカルニチンの再吸収にも 関わっており, 体内カルニチンの恒常性維持に対し て大きく寄与していることが示唆されている。この 機能異常が全身的な血中カルニチンの低下を招いて いるものと推測されていたが，その分子的実体につ いては長い間明らかにされず，SCD 発症の分子メ カニズムは謎に包まれていた. ${ }^{135)}$

1988 年, 金沢大学動物実験施設で自然発症的に カルニチン欠乏症状を引き起こす Juvenile Visceral

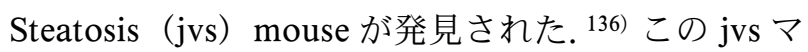
ウスの病態並びに生化学的所見はヒト SCD と良く 一致していることから SCD のモデル動物として位
置付けられ，第 11 番染色体の領域にマウス SCD の原因となるカルニチントランスポーターをコード する遺伝子が存在すると推測された。一方，1998 年小泉らは一人の患者を含むただ 1 つの家系を用い て変異遺伝子の染色体上の位置を非常に細かく絞り 込むことに成功した. ${ }^{135,136)} こ の$ 絞り込まれた位置 は CDSP (Carnitine Deficiency Systemic Primary Locus）遺伝子座と命名され，ヒ卜第 5 番染色体の q31.1にマップされた. この位置はjvs マウスで推 定された領域に相当するものであり，ヒトとマウス は同一の遺伝子変異, すなわちカルニチントランス ポーターの機能異常により SCD 症状が惹起される ことを強く示唆するものであった。

7-1. 有機カチオントランスポーター OCTN フ アミリーの構造と機能＼cjkstart新規な有機カチオントラ ンスポーター遺伝子の単離を模索していた著者ら は, 有機カチオン系薬物及び内因性物質を輸送する 新規トランスポーターファミリー OCTN の遺伝子 を発見し，その機能解析に成功した. ${ }^{137-146)}$

最初に発見したヒト OCTN1（hOCTN1）は既存 の有機カチオントランスポーター OCT ファミリー や有機アニオントランスポーター OAT ファミリー とそれぞれ約 $30 \%$ の相同性を有し，さらに 1 つの ATP 結合サイト（nucleoside 結合部位）を所有し ていることから OCTN と命名した. ${ }^{137)}$ hOCTN1 は その発現が肝臟や腎臓など組織特異性の高い OCT, OAT ファミリーと異なり, 腎臓, 小腸，骨格筋， 脳, 肺など広い組織分布を示したが, 成人の肝臓に は認められなかった。 hOCTN1 はそのアミノ酸配 列から推測されたように, 種々の有機力チオン性化 合物に対する輸送活性を有しており，その特性は $\mathrm{pH}$ 感受性でありかつ膜電位非依存性であることが 確認された。137,138)さらに, 著者らはヒト腎蔵に hOCTN1 と高い相同性（75.8\%）を有する新規な 遺伝子が存在することを見出し, クローニング並び に機能解析を行った. ${ }^{138)}$ 新規遺伝子のコードする タンパク質は hOCTN1 との相同性の高さからヒト OCTN2（hOCTN2）と名付けたが，hOCTN2 にお いては hOCTN1 の良い基質であったテトラエチル アンモニウム（TEA）の輸送活性は hOCTN1 のそ れと比較し低いものであった。 また， $\mathrm{H}^{+} /$有機力チ オンアンチポーターの基質として報告されているグ アニジンの輸送は全く認められなかった（Fig. 9). 


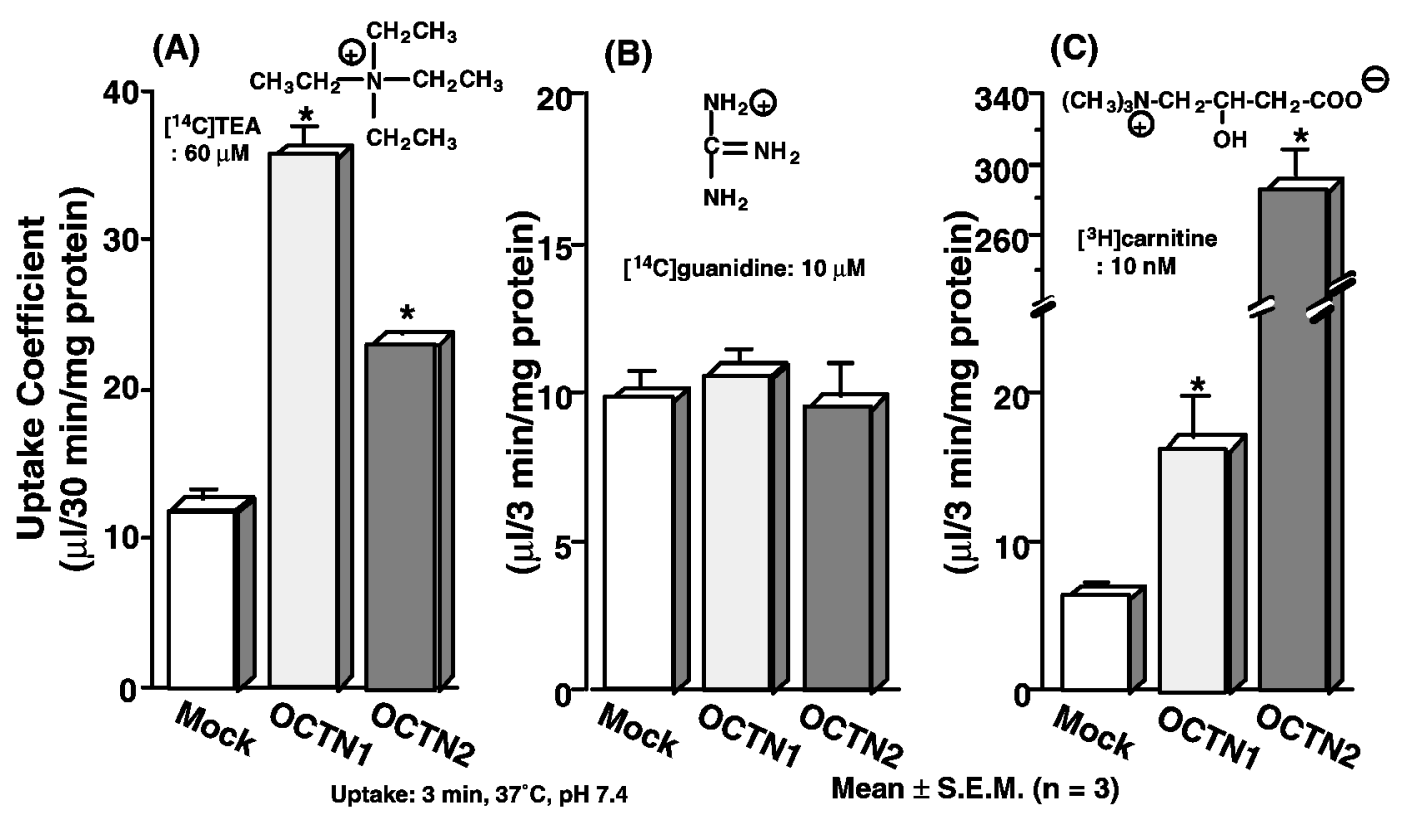

Fig. 9. Uptake of $\left[{ }^{14} \mathrm{C}\right]$ Tetraethylammonium (A), $\left[{ }^{14} \mathrm{C}\right]$ Guanidine (B) and $\mathrm{L}-\left[{ }^{3} \mathrm{H}\right]$ Carnitine (C) by OCTN1 or OCTN2 Transfected HEK293 Cells

著者らは hOCTN2 のノーザンブロット解析から腎 臓, 骨格筋, 胎盤, 心臓などに強く発現し, その他 肝臟，脳，小腸などあらゆる組織に発現しているこ とから, 生体内で重要な働きをする内因性物質の輸 送に関わつていることかつエネルギー要求性の高い 組織に高発現していることに着目し, 脂肪酸代謝に 重要な両性イオン化合物であるカルニチンをその候 補として挙げた。その結果, hOCTN2 のカルニチ ン取り込みは著しく, さらにこの取り込みは $\mathrm{Na}^{+}$ に完全に依存する特性を示した。しかも，親和性 $(\mathrm{Km}: 4.3 \mu \mathrm{M})$, 基質認識性など種々の輸送特性は 過去に組織・細胞レベルで報告されている $\mathrm{Na}^{+}$依 存性の高親和性カルニチントランスポーターの特性 と一致するものであり，「幻のカルニチントランス ポーター」の実体をつかんだことを確信した. ${ }^{138)}$

著者らは OCTN2 の腎臓での発現部位を調べるた めにマウス OCTN2 抗体を用いたマウス腎臟切片の 免疫染色を行い, OCTN2 が腎尿細管刷子縁膜側に

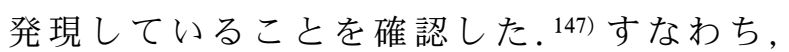
OCTN2 が腎尿細管で実際にカルニチンの効率的な 再吸収に関わっていることを強く示唆するものであ る.

7-2. OCTN2 遺伝子変異が引き起こす SCD カルニチントランスポーター OCTN2 の発見で最も 興味が持たれたのは，SCD 患者やjvs マウスにお
いてこの遺伝子変異が原因となっているか否かであ つた。そこで, 初めに hOCTN2 の配列情報を基に 正常及び jvs マウス OCTN2 遺伝子クローニングを 行い, 遺伝子並びに機能解析を試みた。 その結果,

Fig. 10 に示されるように jvs マウス OCTN2 では正 常マウスと比較し，352 番目のロイシンをコードし ているコドン（CTG）がアルギニンをコードする コドン（CGG）へと一塩基置換が起こっていた。 また, jvs マウスの OCTN2 発現細胞では $\mathrm{Na}^{+}$存在 下でもカルニチン輸送活性は著しく低く, カルニチ ントランスポーターとしての機能を欠損しているこ とが明らかとなった. ${ }^{139-141)}$ すなわち，jvs マウス では OCTN2 遺伝子のたつた 1 つの塩基置換が全身 性カルニチン欠乏症を引き起こす原因となっている ものと考えられた. ${ }^{139)}$

ヒトについては 3 組の互いに血縁関係のない $\mathrm{SCD}$ 家系における OCTN2 遺伝子の解析を行っ た。 その結果，いずれの家系においても OCTN2 遺 伝子の変異が存在することが明らかとなつた. 変異 はフレームシフトに基づくストップコドンの出現に より不完全なタンパク質が生成する変異, 一部配列 の欠損, スプライシング部位の変異が見出された （Fig. 10）が，いずれも成熟夕ンパク合成及び輸送 機能を失っているものと考えられた. また，すべて の家系において SCD 患者は両親からそれぞれ受け 


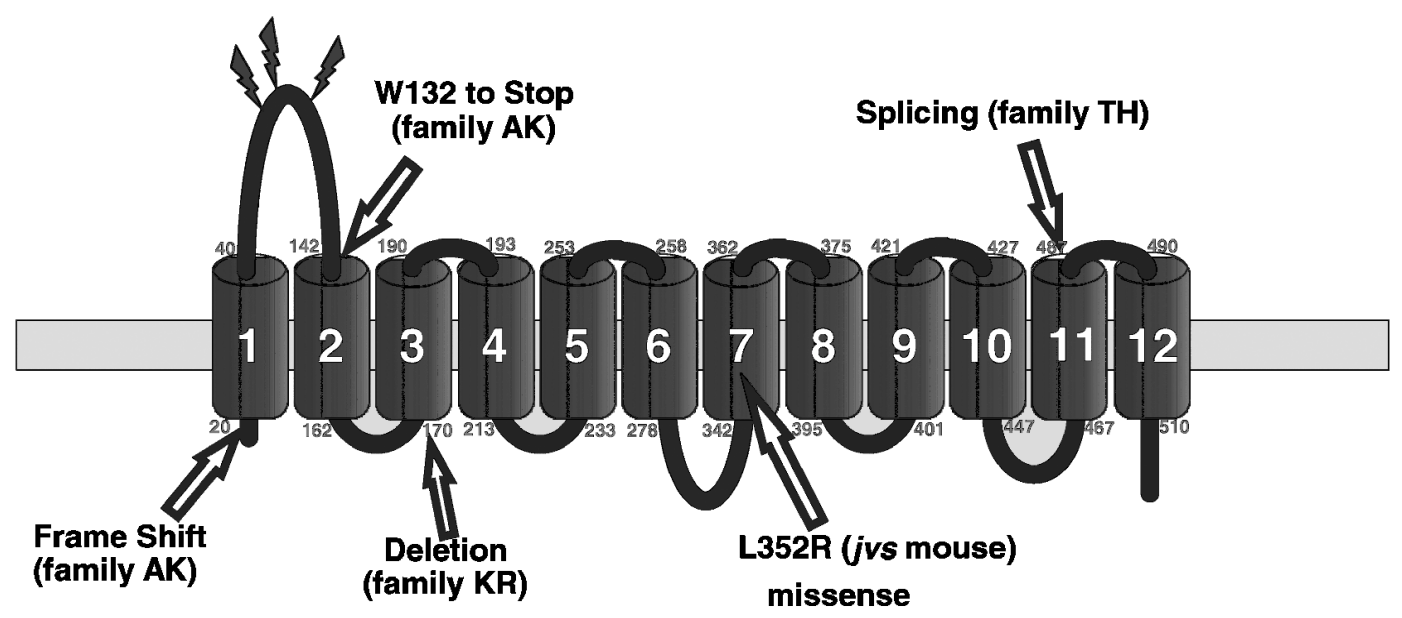

Fig. 10. Predicted Secondary Structure of OCTN2 and Mutations in JVS Mouse and in Japanese Patients with Systemic Carnitine Deficiency (SCD)

継いだ 2 つの OCTN2 遺伝子の両方に変異を持ち, OCTN2のカルニチン輸送機能の完全な損失が SCD 発症の原因であることが示された。こうし て，著者らはSCDがカルニチントランスポーター OCTN2 の機能損失変異により発症していることを 世界で初めて証明することに成功した. ${ }^{136)}$ その 後, 種々の研究グループにより SCD 患者の様々な OCTN2 変異が次々と報告されるに至ってい る. ${ }^{135,144)}$

7-3. SCD の遺伝子診断とOCTN2 遺伝子変異 の発現頻度 SCD の正確な疫学的調査は現在ま で行われておらず, その発現頻度については謎に包 まれており，比較的低い頻度であると考えられてい た. しかし, 変異 OCTN2 遺伝子の頻度について秋 田県で自動車販売を担当する男女を対象に分析した 結果, OCTN2 遺伝子変異の頻度は $1.01 \%$ と予想以

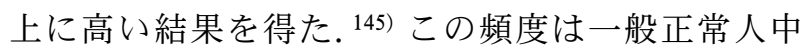
においてへテロで変異 OCTN2 遺伝子を持っている 頻度であり，この值から SCD 発現頻度を見積もる と, 新生児約 $1 / 4$ 万人という驚くべき高さであっ た.この概算を確認するためには全国的な大規模疫 学調査による詳細な検討が必要であると考えている.

OCTN2 遺伝子変異の頻度は SCD のリスクのみ ならずへテロで変異を持つことの健康障害リスクと いう観点からも重要な問題である. ヘテロで変異を 持つ人は正常人と比較し明らかに血中カルニチンレ ベルが低いことが分かっているが，その恒常的に低 い血中カルニチンレベルが長期的にどのような健康
障害をもたらすかについては明らかではない. 少な くとも高齢者においては心臓, 骨格筋機能などの低 下が想定され, 特に正常高齢者より機能低下の促進 が予想される.これらの謎については OCTN2 遺伝 子変異スクリーニングシステムの開発, それを用い た全国レベルの大規模な疫学調査の実施とその結果 を待たねばならない.

7-4. OCTN2 のカルニチン及び有機カチオン輸 送における多機能性著者らは hOCTN2 が両性 イオン化合物であるカルニチン類を $\mathrm{Na}^{+}$依存的に 輸送することの夕ならず抗ヒスタミン薬ピリラミン, $\mathrm{Ca}$ 拮抗薬ベラパミルなどの種々の有機力チオン類 を $\mathrm{Na}^{+}$非依存的に輸送することを見出してい る. 146) すなわち，1つのトランスポーターが異なる 輸送駆動力によりそれぞれ異なる基質を輸送すると いう多機能性を有するものである. 著者らはこのよ うな多機能性を示すトランスポーターを NPT1に おいても発見している. ${ }^{123,124)} \mathrm{NPT} 1$ は, $\mathrm{Na}^{+}$依存 的に無機リン酸を細胞内に取り込むと同時に, $\mathrm{Na}^{+}$ 非依存的に PAH や $\beta$-ラク夕ム抗生物質など有機 アニオンを細胞内から排出する。これまで機能が明 らかにされたトランスポーターのなかでも OCTN2 及びNPT1 以外には見られない, 極めて興味深い 輸送特性である。また, hOCTN2 による $\mathrm{Na}^{+}$依存 的なカルニチン輸送は有機カチオンのみならず，バ ルプロ酸のような有機アニオンなど種々の薬物によ り阻害されることから, 高投与量による長期服用に おける薬物誘導型カルニチン欠乏症あるいはそれに 
基づく腎毒性との部分的関与が示唆されており, 146) 遺伝学的のみならず薬理学並びに毒性学的にも重要 なトランスポーターであると考えられる.

\section{8. おわりに}

薬物の生体認識と化学構造との関連性が解明でき るかどうかが薬物の体内動態の理解，特に経口剂の 開発戦略にとって重要な鍵となる。内因性物質を輸 送するトランスポーター群が上述のように，薬物を 認識・輸送する分子的実体が次々と明らかにされて きている。しかし，組織細胞膜に備わるトランス ポーター群の構造・機能解明に関する分子生物学的 研究はやっと端緒についたばかりである。 トランス ポーター研究は, 生体にとって「必要なもの」と 「不要なもの」とに選別輸送する生体機能の解明に 重要である。また，小腸など限定された組織に発現 するペプチドトランスポーターが腫瘍細胞において 発現していることを利用すれば腫瘍組織のみにペプ チド系抗癌剤をデリバリーすることは可能であると する著者らの戦略 ${ }^{148)}$ からも理解できるように, 将 来は臓器特異的なトランスポーターをターゲットと した創薬・創剤の研究開発が発展するものと期待さ れる。

謝辞本研究は, $\beta$-ラクタム抗生物質の安定 性に関する化学反応速度論的研究を進めたことに端 を発して，種々の新規な発見につながつたものであ り, 本抗生物質に関する研究テーマと大学で研究者 としての道を与えていただき，終始暖かく御支援と 励ましをいただきました恩師山名月中金沢大学名誉 教授に深甚なる謝意を表します。学生としてあるい は同僚として本研究プロジェクトに参加し，協力い ただいた北陸大薬学部 宮本悦子教授，共立薬科大 学 中島恵美教授, 東北大大学院薬学研究科 寺崎 哲也教授，東京理科大学薬学部 玉井郁巳教授，昭 和大学薬学部 佐藤 均教授, 帝京大学薬学部 出 口 芳春助教授, 金沢大学薬学部 崔 吉道博士に 感謝致します。生理学的モデル構築に協力いただい た故市村藤雄・金沢大学名誉教授，金沢大学医学部 附属病院薬剂部 河原昌美氏に深謝します。ペプチ ドトランスポーター研究に協力と助言を頂いた星 猛元静岡県立大学長, 米国ジョージア医科大学 F. H. Leibach 教授，米国ミシガン大学薬学部 G. L. Amidon 教授, 米国ラトガー大学薬学部 P.J.
Sinko 教授, 徳島大学医学部 武田英二教授 - 宮本 賢一教授・白神俊幸博士，金沢大学がん研究所 佐 々木环磨教授に感謝致します, 塩基性ぺプチドの合 成と吸着介在エンドサイトーシス研究に協力いただ いた近畿大学理工学部 若宮 建昭教授, アベンテ ィス・ファーマ侏・ 志村武貞博士・田端 滋博士に 感謝します。P-糖タンパク質, トランスポーター 遺伝子やその発現系に関する研究では，金沢大学医 学部 山本 博教授・東田 陽博教授・ 山下純宏教 授 - 井関 尚一教授 - 山嶋哲盛助教授, 福井県立大 学 森谷修三教授, エーザイ侏・加藤 晃良博士, キノロン抗菌薬に関する研究では, 東京大学大学院 薬学系研究科 - 杉山 雄一教授, 加藤 将夫博士 (現金沢大学薬学部助教授), 大塚製薬侏) 笹部裕行 博士，北陸製薬(侏) - 加藤 日出男博士 - 永田 治博 士 - 桶崎 英一博士，村田 光夫氏，持田製薬侏荻 原 挀男博士に, OCTN2 とカルニチン欠乏症の関 連研究では, 早川純一郎・金沢大学名誉教授, 金沢 大学医学部附属動物実験施設 浅野雅秀教授 - 橋本 憲佳博士 -二階堂 浩子博士, 金沢大学医学部附属 病院薬剂部 宮本謙一教授・横川弘一助教授, 中外 製薬侏・根津淳一博士・奥 飛鳥，嶋根みゆき氏, 京都大学医学部 小泉昭夫教授, 東北大学医学部 大浦敏博助教授, 久留米大学医学部 松石豊次郎助 教授, 京都大学大学院薬学研究科 辻本豪三教授, 田辺製薬怢大橋 力也博士にそれぞれ多大の協力を いただいた。ここに厚く御礼を申し上げます。

製剂学研究室 (現創剂科学研究室) にて本研究に 参加された多くの博士課程, 修士課程, 学部におけ る学生諸氏と研究生，その他多くの共同研究者の協 力によって本研究が達成できたものであり，これら の諸氏に深く感謝します。

さらに, 研究費の一部は文部省科学研究費, 厚生 省がん研究助成金, ヒューマンサイエンス財団創薬 科学総合研究事業及び創薬等ヒューマンサイエンス 総合研究事業研究費, 戦略的基礎研究推進事業 (CREST) 研究費, 武田科学振興財団助成金, 東京 生化学研究会研究助成金, 臨床薬理研究振興財団研 究奨励金, 上原記念生命科学財団研究助成金, 中富 健康科学振興財団研究助成金によった.ここに記し て深く感謝の意を表します。 


\section{REFERENCES}

1) Tsuji A., Yoshikawa T., Nishide K., Minami H., Kimura M., Nakashima E., Terasaki T., Miyamoto E, Nightingale C. H., Yamana T., J. Pharm. Sci., 72, 1239-1252 (1983) .

2) Tsuji A., Nishide K., Minami H., Nakashima E., Terasaki T., Yamana, T., Drug Metab. Dispos., 13, 729-739 (1985).

3) Tsuji A., Sato H., Tamai I., Adachi H., Nishihara T., Ishiguro M., Ohnuma N., Noguchi T., Drug Metab. Dispos., 18, 245-252 (1990).

4) Tsuji A., Terasaki T., Imaeda N., Nishide K., Nakashima E., J. Pharmacobio-Dyn., 8, 167174 (1985).

5) Deguchi Y., Koshida R., Nakashima E., Watanabe R., Taniguchi N., Ichimura F., Tsuji A., J. Pharm. Sci., 77, 674-678 (1988).

6) Tsuji A., Terasaki T., Imaeda N., Nishide K., Tamai I., J. Pharm. Sci., 78, 535-540 (1989).

7) Koshida R., Nakashima E., Taniguchi N., Tsuji A., Benet L. Z., Ichimura F., Pharm. Res., 6, 486-491 (1989).

8) Sato H., Yoshioka K., Terasaki T., Tsuji A., Biochim. Biophys. Acta, 1073, 442-450 (1991).

9) Sato H., Terasaki T., Okumura K., Tsuji A., Pharm. Res., 8, 563-569 (1991).

10) Ichimura F., Yokogawa K., Yamana T., Tsuji A., Mizukami Y., Int. J. Pharm., 15, 321-333 (1983) .

11) Ichimura F., Yokogawa K., Yamana T., Tsuji A., Yamamoto K., Murakami S., Mizukami Y., Int. J. Pharm., 19, 75-88 (1984).

12) Okezaki E., Terasaki T., Nakamura M., Nagata O., Kato H., Tsuji A., Drug Metab. Dispos., 16, 865-874 (1988).

13) Nagata O., Murata M., Kato H., Terasaki T., Sato H., Tsuji A., Drug Metab. Dispos., 18, 902-910 (1990).

14) Nakashima E., Matsushita R., Ohshima T., Tsuji A., Ichimura F., Drug Metab. Dispos., 23, 1220-1224 (1995).

15) Kawahara M., Nanbo T., Tsuji A., Biopharm. Drug Dispos., 19, 445-453 (1998).

16) Kawahara M., Sakata A., Miyashita T., Tamai I., Tsuji A., J. Pharm. Sci., 88, 12811287 (2000).

17) Deguchi Y., Terasaki T., Kawasaki S., Tsuji
A., J. Pharmacobio-Dyn., 14, 483-492 (1991).

18) Deguchi Y., Terasaki T., Yamada H., Tsuji A., J. Pharmacobio-Dyn., 15, 79-89 (1992).

19) Araki H., Ogake N., Minami S., Watanabe Y., Narita H., Tamai I., Tsuji A., J. Pharm. Pharmacol., 49, 1141-1144 (1997).

20) Terasaki T., Deguchi Y., Kasama Y., Pardridge W. M., Tsuji A., Int. J. Pharm., 81, 143-152 (1992).

21) Terasaki T., Yakubutsu Dotai, 7, 89-98 (1995).

22) Tsuji A., Miyamoto E., Kagami I., Sakaguchi H., Yamana, T., J. Pharm. Sci., 67, 17011704 (1978).

23) Tsuji A., Nakashima E., Kagami I., Honjo N., Yamana, T., J. Pharm. Pharmacol., 29, 707-708 (1977).

24) Tsuji A., Nakashima E., Asano T., Nakashima R., Yamana, T., J. Pharm. Pharmacol., 31, 718-720 (1979).

25) Tsuji A., Nakashima E., Kagami I., Yamana T., J. Pharm. Sci., 70, 768-772 (1981).

26) Tsuji A., Nakashima E., Kagami I., Yamana Y., J. Pharm. Sci., 70, 772-777 (1981).

27) Nakashima E., Tsuji A., Kagatani S., Yamana, T., J. Pharmacobio-Dyn., 7, 452464 (1984).

28) Nakashima E., Tsuji A., Mizuo H., Yamana T., Biochem. Pharmacol., 33, 3345-3352 (1984).

29) Tsuji A., Hirooka H., Tamai I., Terasaki T., J. Antibiotics, 39, 1592-1597 (1986) .

30) Tsuji A., Tamai I., Hirooka H., Terasaki T., Biochem. Pharmacol., 36, 565-567 (1987).

31) Tsuji A., Hirooka H., Terasaki T., Tamai I., Nakashima, E., J. Pharm. Pharmacol., 39, 272-277 (1987).

32) Tsuji A., Terasaki T., Tamai I., Hirooka H., J. Pharmacol. Exp. Ther., 241, 594-601 (1987).

33) Tamai I., Ling H.-Y., Simanjuntak M. T., Nishikido J., Tsuji A., J. Pharm. Pharmacol., 40, 320-324 (1988).

34) Tsuji A., Tamai I., Nakanishi M., Terasaki T., Hamano S., J. Pharm. Pharmacol., 45, 996-998 (1993).

35) Tamai I., Tomizawa N., Kadowaki A., Terasaki T., Nakayama K., Higashida H., Tsuji 
A., Biochem. Pharmacol., 48, 881-888 (1994).

36) Tamai I., Tomizawa N., Takeuchi T., Nakayama K., Higashida H., Tsuji A., J. Pharmacol. Exp. Ther., 273, 26-31 (1995).

37) Miyamoto K., Shiraga T., Morita K., Yamamoto H., Haga H., Taketani Y., Tamai I., Sai Y., Tsuji A., Takeda E., Biochim. Biophys. Acta, 1305, 34-38 (1996).

38) Tamai I., Nakanishi T., Hayashi K., Terao T., Sai Y., Shiraga T., Miyamoto K., Takeda E., Higashida H., Tsuji, A., J. Pharm. Pharmacol., 49, 796-801 (1997).

39) Sai Y., Tamai I., Sumikawa H., Hayashi K., Amano O., Numata M., Iseki S., Tsuji, A., FEBS Lett, 392, 25-29 (1996).

40) Shiraga T., Miyamoto K., Tanaka H., Yamamoto H., Taketani Y., Moriya K., Tamai I., Tsuji A., Takeda, E., Gastroenterology, 116, 354-362 (1999).

41) Tsuji A., "Peptide-Based Drug Design: Controlling Transport and Metabolism," eds. by Taylor M. D., Amidon G. L., American Chemical Society, Washington D.C., 1995, pp. 101-134.

42) Tsuji A., Tamai I., Pharm. Res., 13, 964-977 (1996).

43) Tamai I., Tsuji A., Adv. Drug Deliv. Rev., 20, 5-32 (1996).

44) Terasaki T., Kadowaki A., Higashida H., Nakayama K., Tamai I., Tsuji A., Biol. Pharm. Bull., 16, 493-496 (1993).

45) Fei Y.-J., Kanai Y., Nussberger S., Ganapathy V., Leibach F. H., Romero M. F., Singh S. K., Boron W. F., Hediger M. A., Nature, 368, 563 (1994).

46) Saito H., Okuda M., Terada T., Sasaki S., Inui K., J. Pharmacol. Exp. Ther., 275, 16311637 (1995).

47) Liang R., Fei Y.-J., Presad P. D., Ramamoorthy S., Han H., Yang-Feng T. L., Hediger M. A., Ganapathy V., Leibach, F. H., J. Biol. Chem., 270, 6456-6463 (1995).

48) Balimanen P. V., Tamai I., Guo A., Nakanishi T., Kitada H., Leibach F. H., Tsuji A., Sinko, P. J., Biochem. Biophys. Res. Commun., 250, 246-251 (1998).

49) Tsuji A., Tamai I., Nakanishi M., Amidon G. L., Pharm. Res., 7, 308-309 (1990).
50) Tamai I., Nakanishi T., Nakahara H., Sai Y., Ganapathy V., Leibach F. H., Tsuji A., J. Pharm. Sci., 87, 1542-1546 (1998).

51) Tsuji A., Simanjuntak M. T., Tamai I., Terasaki T., J. Pharm. Sci., 79, 1123-1124 (1990) .

52) Simanjuntak M. T., Tamai I., Terasaki T., Tsuji A., J. Pharmacobio-Dyn., 13, 301-309 (1990).

53) Simanjuntak M. T., Terasaki T., Tamai I., Tsuji A., J. Pharmacobio-Dyn., 14, 501-508 (1991).

54) Tsuji A., Takanaga H., Tamai I., Terasaki T., Pharm. Res., 11, 30-37 (1994).

55) Takanaga H., Tamai I., Tsuji A., J. Pharm. Pharmacol., 46, 567-570 (1994).

56) Tamai I., Takanaga H., Ogihara T., Yoneda M., Tsuji A., Pharm. Res., 12, 1727-1732 (1995).

57) Takanaga H., Maeda H., Yabuuchi H., Tamai I., Higashida H., Tsuji A., J. Pharm. Pharmacol., 48, 1073-1077 (1996).

58) Ogihara T., Tamai I., Takanaga H., Sai Y., Tsuji A., Pharm. Res., 13, 1828-1832 (1996).

59) Tamai I., Takanaga H., Maeda H., Yabuuchi H., Sai Y., Suzuki Y., Tsuji A., J. Pharm. Pharmacol., 49, 108-112 (1997).

60) Ogihara T., Tamai I., Tsuji A., Pharm. Res., 15, 620-625 (1998).

61) Ogihara T., Tamai I., Tsuji A., J. Pharm. Sci., 88, 1217-1221 (1999).

62) Garcia C. K., Goldstein J. L., Pathak R. K., Anderson R. G. W., Brown M. S., Cell, 76, 755 (1994).

63) Tamai I., Takanaga H., Maeda H., Sai Y., Ogihara T., Higashida H., Tsuji A., Biochem. Biophys. Res. Commun., 214, 482-489 (1995).

64) Takanaga H., Tamai I., Inaba S., Sai Y., Higashida H., Yamamoto H., Tsuji A., Biochem. Biophys. Res. Commun., 217, 370377 (1995).

65) Tamai I., Sai Y., Ono A., Kido Y., Yabuuchi H., Takanaga H., Satoh E., Ogihara T., Amano O., Iseki S., Tsuji A., J. Pharm. Pharmacol., 51, 1113-1121 (1999).

66) Kido Y., Tamai I., Okamoto M., Suzuki F., Tsuji A., Pharm. Res., 17, 55-62 (2000).

67) Yabuuchi H., Tamai I., Sai Y., Tsuji A., 
Pharm. Res., 15, 411-416 (1998).

68) Tsuji A., Tamai I., Biochem. Pharmacol., 38, 1019-1022 (1989).

69) Ishizawa T., Tsuji A., Tamai I., Terasaki T., Hosoi K., Fukatsu, S., J. Pharmacobio-Dyn., 13, 292-300 (1990).

70) Ishizawa T., Sadahiro S., Hosoi K., Tamai I., Terasaki T., Tsuji A., J. Pharmacobio-Dyn., 15, 481-489 (1992).

71) Tamai I., Tsuji A., Adv. Drug Deliv. Rev., 19, 401-424 (1996).

72) Tsuji A., Hamano S., Asano T., Nakashima E., Yamana T., Mitsuhashi S., J. Pharm. Sci., 73, 1418-1422 (1984).

73) Hamano S., Tsuji A., Asano T., Tamai I., Nakashima E., Yamana T., Mitsuhashi S., $J$. Pharm. Sci., 73, 1422-1427 (1984).

74) Sato H., Okezaki E., Yamamoto S., Nagata O., Kato H., Tsuji A., J. Pharmacobio-Dyn., 11, 386-394 (1988).

75) Okezaki E., Terasaki T., Nakamura M., Nagata O., Kato H., Tsuji A., Drug Metab. Dispos., 16, 865-874 (1988).

76) Tamai I., Safa A. R., J. Biol. Chem., 265, 16509-16513 (1990).

77) Tsuji A., Tamai I., Adv. Drug Deliv. Rev., 25, 287-298 (1997).

78) Tsuji A., Tamai I., Adv. Drug Deliv. Rev., 36, 277-290 (1999).

79) Tamai A., Tsuji A., J. Pharm. Sci., 89, 13711388 (2000).

80) Yamashima T., Moritani S., Tsuruo T., Yamashita J., Life Sci., 51, 1427-1437 (1992).

81) Tsuji A., Tamai I., Sakata A., Biochem. Pharmacol., 46, 1096-1099 (1993).

82) Sakata A., Tamai I., Kawazu K., Deguchi Y., Ohnishi T., Saheki A., Tsuji A., Biochem. Pharmacol., 48, 1989-1992 (1994).

83) Ohnishi T., Tamai I., Sakanaka K., Sakata A., Yamashima T., Yamashita J., Tsuji A., Biochem. Pharmacol., 49, 1541-1544 (1955).

84) Schinkel A. H., Smit J. J. M, Tellingen O van, Beijnen J. H., Wagenaar E., Deemter L van, Mol C. A. A. M., van der Valk M. A., Robanus-Maandag E. C., te Riele H. P. J., Berns A. Borst J. M. P., Cell, 77, 491-502 (1994).

85) Murata M., Tamai I., Kato H., Nagata O., Kato H., Tsuji A., J. Pharmacol. Exp. Ther.,
290, 51-57 (1999).

86) Yokogawa K., Takahashi M., Tamai I., Konishi H., Nomura M., Moritani S., Miyamoto K., Tsuji A., Pharm. Res., 16, 1213 -1218 (1999).

87) Terao T., Hisanaga E., Sai Y., Tamai I., Tsuji A., J. Pharm. Pharmacol., 48, 1083-1089 (1996).

88) Tamai I., Saheki A., Saitoh R., Sai Y., Yamada I., Tsuji A., J. Pharmacol. Exp. Ther., 283, 108-115 (1997).

89) Naruhashi K., Tamai I., Sai Y., Suzuki N., Tsuji A., J. Pharm. Pharmcol., 53, 73-81 (2001).

90) Naruhashi K,, Tamai I., Inoue N., Muraoka H., Sai Y., Suzuki N., Tsuji A., J. Pharm. Pharmacol., 53, 699-709 (2001).

91) Naruhashi K,, Tamai I., Inoue N., Muraoka H., Sai Y., Suzuki N., Tsuji A., Antimicrob. Agents Chemother., 46, 344-349 (2002).

92) Kido Y., Tamai I., Uchino H., Sai Y., Suzuki F., Tsuji A., J. Pharm. Pharmacol., 53, 497503 (2001).

93) Kido Y., Tamai I., Ohnari A., Sai Y., Kagami T., Nezu J., Nikaido H., Hashimoto N., Asano M., Tsuji A., J. Neurochem., 79, 959-969 (2001).

94) Kido Y., Tamai I., Nakanishi T., Kagami T., Hirosawa I., Sai Y., Tsuji A., Drug Metabol. Pharmacokin., 17, 34-41 (2002).

95) Kang Y. S., Terasaki T., Tsuji A., J. Pharmacobio-Dyn., 13, 158-163 (1990).

96) Terasaki T., Kang Y. S., Ohnishi T., Tsuji A., J. Pharm. Pharmacol., 43, 172-176 (1991).

97) Kido Y., Tamai I., Okamoto M., Suzuki F., Tsuji A., Pharm. Res., 17, 55-62 (2000).

98) Terasaki T., Takakuwa S., Moritani S., Tsuji A., J. Pharmacol. Exp.Ther., 258, 932-937 (1991).

99) Tsuji A., Saheki A., Tamai I., Terasaki, T., $J$. Pharmacol. Exp. Ther., 267, 1085-1090 (1993).

100) Saheki A., Terasaki T., Tamai I., Tsuji A., Pharm. Res., 11, 305-311 (1994).

101) Kang Y. S., Terasaki T., Ohnishi T., Tsuji A., J. Pharmacobio-Dyn., 13, 353-360 (1990) .

102) Kang Y. S., Terasaki T., Tsuji A., J. Pharmacobio-Dyn., 13, 10-19 (1990).

103) Yamazaki M., Fukuoka H., Nagata O., Kato 
H., Ito Y., Terasaki T., Tsuji A., Biol. Pharm. Bull., 17, 676-679 (1994).

104) Yamazaki M., Terasaki T., Yoshioka K., Nagata O., Kato H., Ito Y., Tsuji A., Pharm. Res., 11, 975-978 (1994).

105) Yamazaki M., Terasaki T., Yoshioka K., Nagata O., Kato H., Ito Y., Tsuji A., Pharm. Res., 11, 1516-1518 (1994).

106) Tamai I., Kido Y., Yamashita J., Sai Y., Tsuji A., J. Drug Targeting, 8, 383-393 (2000).

107) Terasaki T., Deguchi Y., Sato H., Hirai K., Tsuji A., Pharm. Res., 8, 815-820 (1991).

108) Shimura T., Tabata S., Ohnishi T., Terasaki T., Tsuji A., J. Pharmacol. Exp. Ther., 258, 459-465 (1991).

109) Terasaki T., Takakuwa S., Saheki A., Moritani S., Shimura T., Tabata S., Tsuji A., Pharm. Res., 9, 529-534 (1992).

110) Shimura T., Tabata S., Terasaki T., Deguchi Y., Tsuji A., J. Pharm. Pharmacol., 44, 583588 (1992).

111) Tamai I., Sai Y., Kobayashi H., Kamata M., Wakamiya T., Tsuji A., J. Pharmacol. Exp. Ther., 280, 410-415 (1997).

112) Wakamiya T., Kamata M., Kusumoto S., Kobayashi H., Sai Y., Tamai I., Tsuji A., Bull. Chem. Soc. Jpn., 71, 699-709 (1998).

113) Sai Y., Kajita M., Tamai I., Kamata M., Wakama J., Wakamiya T., Tsuji A., Bioorg. Med. Chem., 6, 841-848 (1998).

114) Sai Y., Kajita M., Tamai I., Wakama J., Wakamiya T., Tsuji A., Pharm. Res., 15, 1305-1309 (1998).

115) Sai Y., Kajita M., Tamai I., Wakama J., Wakamiya T., Tsuji A., Am. J. Physiol., 275, G514-520 (1998).

116) Tsuji A., Terasaki T., Tamai I., Nakashima E., Takanosu K., J. Pharm. Pharmacol., 37, 55-57 (1985).

117) Tsuji A., Terasaki T., Takanosu K., Tamai I., Nakashima E., Biochem. Pharmacol., 35, 151 -158 (1986).

118) Terasaki T., Tamai I., Takanosu K., Nakashima E., Tsuji A., J. Pharmacobio-Dyn., 9, 1828 (1986).

119) Tamai I., Tsuji A., J. Antibiotics, 40, 533-541 (1987) .

120) Tamai I., Tsuji A., J. Pharmacol. Exp. Ther., 246, 338-344 (1988).
121) Tsuji A., Terasaki T., Tamai I., Takeda K., J. Pharmacol. Exp. Ther., 253, 315-320 (1990).

122) Tamai I., Maekawa T., Tsuji A., J. Pharmacol. Exp. Ther., 253, 537-544 (1990).

123) Yabuuchi H., Tamai I., Morita K., Kouda K., Miyamoto K., Takeda E., Tsuji A., J. Pharmacol. Exp. Ther., 286, 1391-1396 (1998).

124) Uchino H., Tamai I., Yabuuchi H., China K., Miyamoto K., Takeda E., Tsuji A. Antimicrob. Agents Chemother., 44, 574-577 (2000).

125) Tsuji A., Tamai I., "Membrane Transporters as Drug Targets,"’ eds. by Amidon G. L., Sadee W., Pharmaceutical Biotechnology, 12: Kluwer Academic/Plenum Publishers, New York, 1999, pp. 471-491.

126) Tamai I., Nezu J., Uchino H., Sai Y., Oku A., Shimane M., Tsuji A., Biochem. Biophys. Res. Commun., 273, 251-260 (2000).

127) Tamai I., Nozawa T., Koshida M., Nezu J., Sai Y., Tsuji A., Pharm. Res., 18, 1262-1269 (2001).

128) Bossuyt X., Mueller M., Meier P.J., J. Hepatol., 25, 733-738 (1996).

129) Abe T., Kakyo M., Tokui T., Nakagomi R., Nishio T., Nakai D., Nomura H., Unno M., Suzuki M., Naitoh T., Matsuno S., Yawo H., J. Biol. Chem., 274, 17159-17163 (1999) .

130) Sasabe H., Terasaki T., Tsuji A., Sugiyama Y., J. Pharmacol. Exp. Ther., 282, 162-171 (1997).

131) Sasabe H., Tsuji A., Sugiyama Y., J. Pharmacol. Exp. Ther., 284, 1033-1039 (1998).

132) Murata M., Tamai I., Sai Y., Nagata O., Kato H., Sugiyama Y., Tsuji A., Drug Metab. Dispos., 26, 1113-1119 (1998).

133) Sasabe H., Kato Y., Terasaki T., Tsuji A., Sugiyama Y., Biopharm. Drug Dispos., 20, 151-158 (1999).

134) Murata M., Tamai T., Kato H., Nagata O., Kato H., Tsuji A., J. Pharmacol. Exp. Ther., 290, 51-57 (1999).

135) Sai Y., Tamai I., Tsuji A., $K A S E A A, 38,432-$ 438 (2000).

136) Koizumi H., Nikaido H., Hayakawa J., Nonomura A., Yoneda T., Lab. Anim., 22, 83 -87 (1988).

137) Tamai I., Yabuuchi H., Nezu J., Sai Y., Oku A., Shimane M., Tsuji A., FEBS Lett., 419, 
107-111 (1997).

138) Tamai I., Ohashi R., Nezu J., Yabuuchi H., Oku A., Shimane M., Sai Y., Tsuji A., J. Biol. Chem., 273, 20378-20382 (1998).

139) Nezu J., Tamai I., Oku A., Ohashi R., Yabuuchi R., Hashimoto N., Nikaido H., Sai Y., Koizumi A., Shoji Y., Takada G., Matsuishi T., Yoshino M., Kato H., Ohura T., Tsujimoto G., Hayakawa J., Shimane M., Tsuji A., Nature Genet., 21, 91-94 (1999).

140) Yabuuchi H., Tamai I., Nezu J., Sakamoto K., Oku A., Shimane M., Sai Y., Tsuji A., J. Pharmacol. Exp. Ther., 289, 768-773 (1999).

141) Hashimoto N., Suzuki F., Tamai I., Nikaido H., Kuwajima M., Hayakawa J., Tsuji A., Biochem. Pharmacol., 55, 1729-1732 (1998).

142) Yokogawa K., Miya K., Tamai I., Higashi Y., Nomura M., Miyamoto K., Tsuji A., J. Pharm. Pharmacol., 51, 935-940 (1999).

143) Yokogawa K., Yonekawa M., Tamai I., O- hashi R., Tatsumi Y., Higashi Y., Nomura M., Hashimoto N., Nikaido H., Hayakawa J., Nezu J., Oku A., Shimane M., Miyamoto K., Tsuji A., Hepatology, 30, 997-1001 (1999) .

144) Mayatepek E., Nezu J., Tamai I., Oku A., Katsura M., Shimane M., Tsuji A., Human Mutation, 15, 118 (2000).

145) Koizumi A., Nozaki J., Ohura T., Kayo T., Wada Y., Nezu J., Ohashi R., Tamai I., Shoji Y., Takada G., Kibira S., Matsuishi T., Tsuji A., Am. J. Human Genetics, 8, 2247-2254 (1999)

146) Ohashi R., Tamai I., Yabuuchi H., Nezu J., Oku A., Sai Y., Shimane M., Tsuji A., J. Pharmacol. Exp. Ther., 291, 778-784 (1999) .

147) Tamai I., China K., Sai Y., Kobayashi D., Nezu J., Kawahara E., Tsuji A., Biochim. Biophys. Acta, 1512, 273-284 (2001).

148) Nakanishi T., Tamai I., Sai Y., Sasaki T., Tsuji, A., Can. Res., 57, 4118-4132 (1999). 